\title{
Benthic metabolism and nutrient regeneration on the continental shelf of Eastern Massachusetts, USA
}

\author{
Charles S. Hopkinson Jr.* , Anne E. Giblin, Jane Tucker
}

The Ecosystems Center, Marine Biological Laboratory, Woods Hole, Massachusetts 02543, USA

\begin{abstract}
Benthic metabolism and nutrient cycling were examined in depositional sediments of Broad Sound, Massachusetts Bay, Stellwagen Basin and Cape Cod Bay between 1990 and 1994 in water 16 to $76 \mathrm{~m}$ deep. Bottom water nitrate and dissolved oxygen concentrations were typically $<10 \mu \mathrm{M}$ and $>70 \%$ of saturation. Sediment organic content was uniformly low at all sites ranging from 1.3 to $2.1 \%$ carbon and 0.1 to $0.3 \%$ nitrogen. Sediment chlorophyll $a$ and phaeopigment concentrations averaged ca 2 and $15 \mathrm{ug} \mathrm{cm}^{-3}$ respectively. Porewater nutrients and sediment-to-water fluxes of $\mathrm{O}_{2}$, dissolved inorganic carbon (DIC), $\mathrm{NH}_{4}{ }^{+}, \mathrm{NO}_{2}{ }^{-}+\mathrm{NO}_{3}{ }^{-}$, urea, $\mathrm{PO}_{4}{ }^{3-}, \mathrm{N}_{2} \mathrm{O}$ and dissolved silicon (DSi), were measured in cores from 4 stations, 4 to 6 times a year, for $2 \mathrm{yr}$, in order to examine seasonal and annual patterns. An additional 8 sites were examined over several years in late summer in order to examine spatial patterns. Average benthic community respiration ranged from 10.6 to $14.3 \mathrm{mmol} \mathrm{O}_{2} \mathrm{~m}^{-2} \mathrm{~d}^{-1}$ or 12.1 to $29.8 \mathrm{mmol} \mathrm{C} \mathrm{m}^{-2} \mathrm{~d}^{-1}$. Within regions, respiration was highest in Broad Sound, followed by Massachusetts Bay, Cape Cod Bay and Stellwagen Basin. Sediments were sources of inorganic N. Annual average dissolved inorganic nitrogen (DIN) fluxes ranged from 0.5 to $1.8 \mathrm{mmol} \mathrm{N} \mathrm{m} \mathrm{d}^{-1}$. For all stations, the flux of DIN was dominated by $\mathrm{NH}_{4}{ }^{+}$. The importance of $\mathrm{NO}_{3}^{-}$ fluxes relative to $\mathrm{NH}_{4}{ }^{+}$increased with increasing depth. For example, in late summer the relative importance of $\mathrm{NO}_{3}{ }^{-}$fluxes increased from 0 to $44 \%$ of total DIN flux between Broad Sound $(<24 \mathrm{~m})$ and Stellwagen Basin $(75 \mathrm{~m})$. Fluxes of $\mathrm{N}_{2} \mathrm{O}$ and urea were always extremely small $(<0.1 \%$ of DIN). Seasonal cycles, which in general tracked bottom-water temperature and phytoplankton sedimentation, were very strong for respiration $\left(\mathrm{O}_{2}\right.$ and DIC) but not for fluxes of $\mathrm{NO}_{3}{ }^{-}$, urea, $\mathrm{N}_{2} \mathrm{O}$, and $\mathrm{PO}_{4}{ }^{3-}$. Annual variation in benthic respiration was ca $25 \%$, similar to that for primary production. Inorganic nutrient fluxes often varied in excess of $100 \%$ between years. Sediment mixing or porewater advection is thought to contribute to high nutrient flux variability. C, N, and P flux stoichiometry deviated substantially from the Redfield ratios, suggesting strong phosphorus retention by sediments and large nitrogen removal via denitrification. DSi fluxes were relatively high, which we attribute to focusing of biogenic material in these depositional sediments. Denitrification exceeded total DIN flux, averaging 1.9 and $1.3 \mathrm{mmol} \mathrm{N} \mathrm{m}^{-2} \mathrm{~d}^{-1}$ in Massachusetts Bay and Stellwagen Basin respectively. The percentage of remineralized $\mathrm{N}$ that was denitrified increased with increasing water depth (from 60 to $72 \%$ for 35 and $75 \mathrm{~m}$ water). Denitrification was supported almost exclusively by coupled nitrification and denitrification. The benthic community decomposed 12 to $22 \%$ of overlying water primary production but only provided 3 to $8 \%$ of the phytoplankton inorganic $\mathrm{N}$ requirement.
\end{abstract}

KEY WORDS: Benthic metabolism - Benthic nutrient regeneration - Porewater nutrients - Denitrification · Cape Cod Bay · Gulf of Maine · Massachusetts Bay

\section{INTRODUCTION}

Sediments play an important role in organic matter degradation and nutrient recycling in aquatic ecosystems. They are especially important in coastal systems

*E-mail: chopkins@mbl.edu because of the magnitude and origin of organic matter and sediment inputs. It is on the continental margin that 30 to $50 \%$ of global primary production occurs and most terrestrially derived particulate organic matter is deposited (Smith \& Hollibaugh 1993). The extent to which organic matter that reaches bottom sediments is reoxidized or buried affects the productivity and qual-

(C) Inter-Research $2001 \cdot$ www.int-res.com 
ity of the overlying water and global $\mathrm{C}$ and $\mathrm{N}$ budgets. While an extensive database on benthic metabolism exists for estuarine coastal systems, a relative paucity of studies limits our understanding of the importance of benthic metabolism on continental shelves.

During the decomposition of organic matter, oxygen and other terminal electron acceptors are consumed and inorganic nutrients are remineralized. With up to $75 \%$ of phytoplankton nutrient requirements supplied from the benthos (Billen 1978), spatial and temporal patterns of benthic nutrient regeneration may be important in regulating spatial and temporal patterns of productivity in overlying water. Seasonally pulsed inputs of organic matter from land can result in gradual release of inorganic nutrients from sediments at times of the year when primary production is most nutrientlimited (Kemp \& Boynton 1984, Boynton \& Kemp 2000). In stratified water columns, benthic oxygen consumption can contribute to hypoxia of bottom waters, which can affect habitat quality and organic matter processing.

Benthic nitrogen cycling is especially critical in coastal systems due to denitrification (Seitzinger \& Giblin 1996). The largest sink (i.e. $>50 \%$ ) in the marine $\mathrm{N}$ cycle is denitrification in continental shelf sediments (Codispoti 1989). Primary production in coastal systems is generally N-limited (Ryther \& Dunstan 1971), and the loss of $\mathrm{N}_{2}$ from sediments during denitrification can regulate productivity and hence the withdrawal of $\mathrm{CO}_{2}$ from the atmosphere. In coastal systems experiencing large anthropogenic $\mathrm{N}$ inputs, denitrification can influence the extent of eutrophication. Benthic nutrient remineralization and denitrification can also influence shifts in phytoplankton assemblages during the growing season (Smayda 1989) by regulating nutrient concentrations in the overlying water and the relative release ratios of $\mathrm{N}: \mathrm{P}: \mathrm{Si}$. In spite of the importance of denitrification, very few studies have examined denitrification on continental shelves. Because of the paucity of denitrification measurements, most estimates of global or regional rates are based on extrapolations of patterns from few sites (see discussion in Seitzinger \& Giblin 1996). Construction of C and $\mathrm{N}$ budgets for shelf systems is difficult because few sites have been investigated and because most of these studies were single 'snapshots' in time (e.g. Devol \& Christensen 1993).

Here we present the results of a multi-year investigation (1990 to 1994) of benthic organic matter decomposition and nutrient flux across the sediment-water interface on the continental shelf of eastern Massachusetts. We examine seasonal patterns of metabolism over several years at 4 sites ranging from 33 to $74 \mathrm{~m}$ in water depth, and spatial patterns in metabolism during late summer at 12 sites ranging from 17 to $76 \mathrm{~m}$ in depth. We compare decomposition estimates from measures of oxygen consumption, total $\mathrm{CO}_{2}$ flux, and alkalinity flux. Fluxes and porewater profiles of inorganic $\mathrm{N}$ and $\mathrm{P}$, urea, $\mathrm{N}_{2} \mathrm{O}$, and $\mathrm{Si}(\mathrm{OH})_{4}$ are presented. Finally, we discuss factors regulating metabolism and nutrient regeneration and the relative importance of benthic processes, including denitrification, in this continental shelf system.

\section{MATERIALS AND METHODS}

Study area. Our study area included Massachusetts and Cape Cod Bays, which are part of the inner shelf system of the Gulf of Maine, along the northeastern Atlantic coast of the USA (Fig. 1). Glaciation and sea-level changes have resulted in a rugged bottom topography with an extremely patchy distribution of modern sedimentary environments (Knebel 1993). Sediment inputs are low as most river drainage basins are small and contain numerous dams, ponds and wetlands.

The bottom of Massachusetts and Cape Cod Bays is characterized as hummocky and rough (Knebel 1993). While the majority of the area is less than $50 \mathrm{~m}$ deep, water depth exceeds $100 \mathrm{~m}$ in Stellwagen Basin. Environments of erosion and non-deposition occur over extensive hummocky areas and atop bathymetric highs. Environments of sediment reworking are found within broad lows and on the lower flanks of topographic highs. Depositional areas that contain relatively finegrained sediments are restricted to broad lows primarily in deep water. Bottom currents are typically $<10 \mathrm{~cm} \mathrm{~s}^{-1}$, but during strong winds and gales, which are common from fall through spring, currents are sufficient to cause episodic resuspension and winnowing of bottom sediments throughout most of the region (Bothner et al. 1990, Butman et al. 1992).

Oceanic circulation is primarily from the northeast. During summer, bottom water circulation is greatly reduced following thermal stratification. Large amounts of inorganic nutrients and suspended solids are discharged mostly into the region around Boston from anthropogenic sources including storm-water runoff and sewage (Kelly 1991). This resulted in decreasing gradients of inorganic nutrients, turbidity and chlorophyll into Massachusetts Bay during our study (Kelly et al. 1995). In fall 2000, the Massachusetts Water Resources Authority (MWRA) moved the site of secondarily treated sewage discharge and storm water runoff from the mouth of Boston Harbor to Massachusetts Bay, ca $15 \mathrm{~km}$ offshore at a depth of $32 \mathrm{~m}$.

Stations and sampling. Twelve stations were sampled periodically between 1990 and 1994 (none in 1991; Table 1). Stations covered a wide range of water 


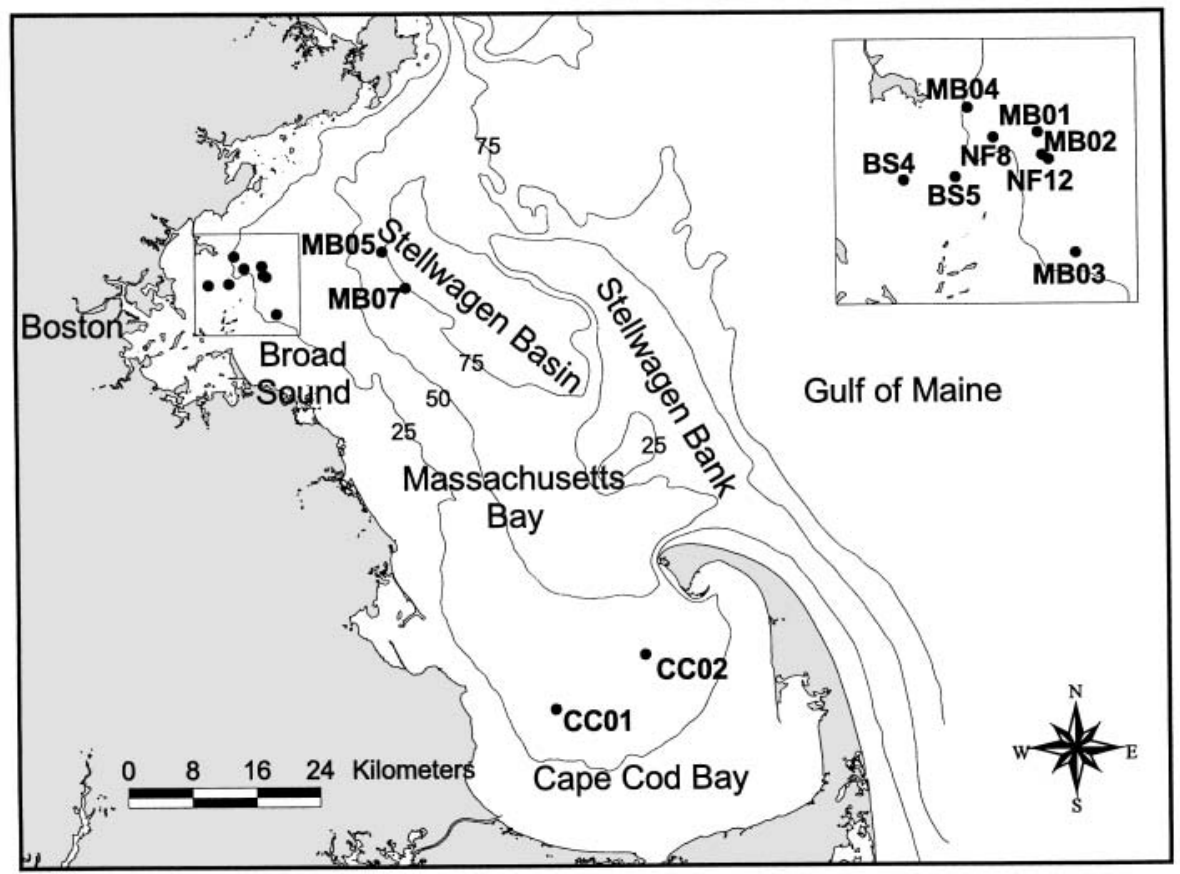

Fig. 1. Map of Massachusetts Bay and Cape Cod Bay region where benthic studies were conducted between 1990 and 1994 , showing 12 stations sampled periodically between 1990 and 1994. Station designations as in Table 1

depths (17 to $76 \mathrm{~m})$, extending from near Boston Harbor (Broad Sound), across mid-depth waters (Massachusetts Bay), out into Stellwagen Basin and south to Cape Cod Bay. Stations were restricted to depositional environments, where sediments range from fine sands to muds. Depositional environments comprise about $29 \%$ of the total bottom area of Massachusetts and Cape Cod Bays (Knebel 1993).

Two stations less than $25 \mathrm{~m}$ deep (Broad Sound) were sampled by SCUBA divers; deeper stations were sampled with a box corer $\left(1600 \mathrm{~cm}^{2}\right.$ or $\left.2500 \mathrm{~cm}^{2}\right)$ with premounted $15 \mathrm{~cm}$ diameter subcorers. Eight of the 12 stations were sampled between 6 and 13 times during the 5 yr period.

At each station, a variety of sediment cores was obtained: 2 to 3 large $15 \mathrm{~cm}$ diameter cores for flux determination, 2 to 3 large $6.5 \mathrm{~cm}$ diameter cores for porewater analysis, and 3 to 4 cores of $2.5 \mathrm{~cm}$ diameter for porosity and solid-phase analyses. Near-bottom water was collected with a diaphragm pump with a series of 20 and $1 \mu \mathrm{m}$ cartridge filters. This water was used to replace water overlying the cores for flux determination.

Benthic respiration and nutrient fluxes. Cores were transported to Woods Hole at in situ bottom-water temperatures and placed in a dark incubator where they were held uncapped, overnight, also at the in situ temperature of the station. Flux measurements began within 12 to $48 \mathrm{~h}$ of sampling. Prior to initiating flux measurements, the overlying water of each core was replaced with filtered seawater. Two $300 \mathrm{ml}$ BOD bottles were filled contemporaneously with the filtered water to correct for respiration and nutrient remineralization in the water overlying the sediments.

Cores were sealed and stirred just enough to prevent constituent stratification. We monitored concentrations of oxygen (DO) in the overlying water throughout the incubation. Incubation duration was such that $\mathrm{O}_{2}$ concentrations remained above $50 \%$ of saturation. Concurrent with $\mathrm{O}_{2}$ measurements, at least 5 time-course samples of the overlying water were withdrawn for dissolved inorganic nitrogen $\left(\mathrm{NH}_{4}{ }^{+}, \mathrm{NO}_{2}{ }^{-}+\mathrm{NO}_{3}{ }^{-}\right)$and urea (1993 to 1994), phosphorus, and silicate (1994) analysis. At the beginning and end of the incubation period, samples were taken for $\mathrm{N}_{2} \mathrm{O}$ (1993 to 1994) and total $\mathrm{CO}_{2}\left(\mathrm{TCO}_{2}: 1992\right.$ to 1994$)$ analysis (1 $\mu \mathrm{M}$ accuracy and precision). Sediment and flux-analysis techniques are summarized in Table 2 .

Benthic respiration (based on $\mathrm{O}_{2}$ [1990 to 1994)] and $\mathrm{CO}_{2}$ [1992 to 1994]) and nutrient flux across the sediment-water interface were calculated as the slope of the constituent concentration versus time (Hopkinson 1985). The values were corrected for changes in the water overlying the cores.

Porewater sampling and analysis. For 1992 to 1994, porewater was extracted in a glove bag under $\mathrm{N}_{2}$. Porewater was sampled in $1 \mathrm{~cm}$ intervals down to $2 \mathrm{~cm}$, $2 \mathrm{~cm}$ intervals to $10 \mathrm{~cm}$, and then in $4 \mathrm{~cm}$ intervals at 
Table 1. Station names, locations, and site characteristics when benthic fluxes were measured. Ranges and means (in parentheses) are reported for stations where fluxes were measured over an annual cycle. Chl a: chlorophyll $a_{i}$ Phaeo: phaeopigments; -: no data

\begin{tabular}{|c|c|c|c|c|c|c|c|c|c|}
\hline Region & Station & $\begin{array}{l}\text { Latitude, } \\
\text { Longitude }\end{array}$ & $\begin{array}{l}\text { Depth } \\
\text { (m) }\end{array}$ & Sediments & ${ }^{\circ} \mathrm{C}$ & $\% \mathrm{C}$ & $\% \mathrm{~N}$ & Chl a & Phaeo \\
\hline \multicolumn{10}{|c|}{ Broad Sound } \\
\hline & BS4 & $42^{\circ} 22.89^{\prime}$ & & & & & & & \\
\hline & & $70^{\circ} 55.09^{\prime}$ & 16.5 & Silty-sand & 14 & - & - & - & - \\
\hline & BS5 & $42^{\circ} 22.96^{\prime}$ & & & & & & & \\
\hline & & $70^{\circ} 53.20^{\prime}$ & 23.8 & $90 \%$ sand & 12 & - & - & - & - \\
\hline \multicolumn{10}{|c|}{ Massachusetts Bay } \\
\hline & MB04 & $42^{\circ} 24.84^{\prime}$ & & & & & & & \\
\hline & & $70^{\circ} 52.72^{\prime}$ & 29.3 & $50 \%$ silt-clay & 13 & - & - & - & - \\
\hline & NF8 & $\begin{array}{l}42^{\circ} 24.03^{\prime} \\
70^{\circ} 51.81^{\prime}\end{array}$ & 30.8 & $50 \%$ silt-clay & 10.8 & 2.0 & 0.22 & 2.8 & 22.7 \\
\hline & MB01 & $42^{\circ} 24.16^{\prime}$ & & & & & & & \\
\hline & & $70^{\circ} 50.19^{\prime}$ & 33.3 & $55 \%$ silt-clay & $1.6-11.8$ & $\begin{array}{c}0.7-2.8 \\
(1.9)\end{array}$ & $\begin{array}{c}0.07-0.52 \\
(0.21)\end{array}$ & $\begin{array}{c}0.78-2.66 \\
(1.74)\end{array}$ & $\begin{array}{c}2.34-21.03 \\
(13.72)\end{array}$ \\
\hline & NF12 & $\begin{array}{l}42^{\circ} 23.42^{\prime} \\
70^{\circ} 49.81^{\prime}\end{array}$ & 34.8 & $55 \%$ silt-clay & 10.1 & 0.94 & 0.11 & - & - \\
\hline & MB02 & $42^{\circ} 23.54^{\prime}$ & & & & & & & \\
\hline & & $70^{\circ} 50.05^{\prime}$ & 35.3 & $50 \%$ silt-clay & $1.6-12.0$ & $\begin{array}{c}0.4-1.45 \\
(1.2)\end{array}$ & $\begin{array}{c}0.03-0.21 \\
\quad(0.11)\end{array}$ & $\begin{array}{c}0.65-5.11 \\
(2.36)\end{array}$ & $\begin{array}{c}3.05-16.47 \\
(11.30)\end{array}$ \\
\hline & МB03 & $42^{\circ} 20.87^{\prime}$ & & & & & & & \\
\hline & & $70^{\circ} 48.90^{\prime}$ & 35.2 & $55 \%$ sand & $1.5-11.3$ & $\begin{array}{c}0.6-3.4 \\
(1.6)\end{array}$ & $\begin{array}{c}0.07-0.22 \\
(1.6)\end{array}$ & $\begin{array}{c}0.72-2.53 \\
\quad(1.70)\end{array}$ & $\begin{array}{c}3.51-22.93 \\
(15.05)\end{array}$ \\
\hline \multicolumn{10}{|c|}{ Cape Cod Bay } \\
\hline & $\mathrm{CC} 01$ & $41^{\circ} 53.89^{\prime}$ & & & & & & & \\
\hline & & $70^{\circ} 24.25^{\prime}$ & 34.1 & $90 \%$ silt-clay & 8.7 & 1.3 & 0.16 & - & - \\
\hline & $\mathrm{CC} 02$ & $41^{\circ} 57.50^{\prime}$ & & & & & & & \\
\hline & & $70^{\circ} 16.01^{\prime}$ & 37.5 & $90 \%$ silt-clay & 8.6 & 2.13 & 0.3 & - & - \\
\hline \multicolumn{10}{|c|}{ Stellwagen Basin } \\
\hline & MB05 & $42^{\circ} 25.05^{\prime}$ & & & & & & & \\
\hline & & $70^{\circ} 39.15^{\prime}$ & 74.4 & Silty-clay & $2.1-10.5$ & $\begin{array}{c}1.1-1.9 \\
(1.4)\end{array}$ & $\begin{array}{c}0.12-0.18 \\
(0.16)\end{array}$ & $\begin{array}{c}1.08-1.77 \\
(1.44)\end{array}$ & $\begin{array}{c}5.90-12.64 \\
(9.98)\end{array}$ \\
\hline & MB07 & $42^{\circ} 22.53$ & & & & & & & \\
\hline & & $70^{\circ} 37.08$ & 75.6 & Silty-clay & 7.6 & 1.53 & 0.18 & - & - \\
\hline
\end{tabular}

greater depths. Porewater was removed by centrifugation. Nutrients, urea, silicate, sulfides, pH and alkalinity in porewaters were analyzed. The sediment redox potential (Eh) was measured in separate cores. Potentials were corrected for the potential of the reference electrode. Occasionally porewater profiles of dissolved $\mathrm{Ca}^{2+}$ were examined to ensure that $\mathrm{TCO}_{2}$ fluxes were due solely to respiration and not to carbonate precipitation or dissolution.

Alkalinity flux was calculated from porewater gradients using a procedure similar to that described by Berner (1980). Alkalinity changes attributable to nitrogen dynamics or sulfide diffusion into the overlying water were not accounted for, as they should be of minor importance to the overall flux. Concentration profiles were fit numerically using a Marquardt (1963) matrix approach to the equation:

$$
C_{z}=C_{\infty}+\left(C_{0}-C_{\infty}\right)\left(\mathrm{e}^{-\alpha z}\right)
$$

where $C_{\infty}$ is the concentration at depth infinity, $C_{0}$ is the concentration at the sediment-water interface, and $C_{z}$ is the concentration at depth $z$. We did not force the fit through the bottom water concentrations at $C_{0}$ (see discussion in Klump \& Martens 1981). In cases where a significant fit could not be obtained we used a linear fit through the data from the surface $(0$ to $1 \mathrm{~cm})$ sediment and the bottom-water concentration. The flux $(J)$ across the sediment-water interface was calculated by:

$$
J=-\phi_{0} D_{\mathrm{s}}(\mathrm{d} C / \mathrm{d} Z)_{z=0}
$$


Table 2. Sediment and flux analysis techniques

\begin{tabular}{|lll|}
\hline Constituent & \multicolumn{1}{c|}{ Description } & Apparatus or Source \\
\hline Core Incubation & Sealed tops - magnetic stirrers & Dornblaser et al. (1989) \\
$\mathrm{DO}$ & Polarographic electrode & Orbisphere Laboratories meter \\
$\mathrm{NH}_{4}{ }^{+}$ & Phenol-hypochlorite & Solórzano (1969) \\
$\mathrm{NO}_{2}{ }^{-} \& \mathrm{NO}_{3}{ }^{-}$ & Cadmium reduction & Alpkem (1986a) \\
$\mathrm{PO}_{4}{ }^{3-}$ & Colorimetric & Murphy \& Riley (1962) \\
$\mathrm{Urea}$ & Colorimetric & Price \& Harrison (1987) \\
$\mathrm{N}_{2} \mathrm{O}$ & GC-ECD & Unpubl. \\
$\mathrm{Silicate}$ & Reduction of stannous chloride & Armstrong (1951) \\
& & Alpkem (1986b) \\
$\mathrm{Sulfide}$ & Colorimetric & Cline (1969) \\
$\mathrm{Ca}$ & Complexometric titration & Tsunogai et al. (1968) \\
Alkalinity & Titration & Edmond (1970) \\
Eh & Platinum electrode & Bohn (1971) \\
Organic C \& N & Acidification-high temperature combustion & Perkin-Elmer CHN \\
Chlorophyll $a$ and phaeopigments & Absorbance: Acetone extract-acidification & Strickland \& Parsons (1972) \\
\hline
\end{tabular}

where $\phi_{0}$ is the porosity at the sediment-water interface, $D_{\mathrm{s}}$ is the bulk diffusion coefficient at the interface, and $(\mathrm{d} C / \mathrm{d} Z)$ is the gradient at the interface. $D_{\mathrm{s}}$ is equal to the molecular diffusion coefficient, $D_{0}$ is corrected for temperature and tortuosity by the formula $D_{\mathrm{s}}=D_{0} \phi_{0}$ (Berner 1980). A value of $1.14 \times 10^{-5}$ was used for $D_{0}$ from the published molecular diffusion coefficient for bicarbonate at $20^{\circ} \mathrm{C}$ (Li \& Gregory 1974).

Calcium fluxes were determined at MB01 and MB02 in October 1993. Calcium concentrations were measured with less than $0.1 \%$ error.

Porosity and bulk constituents. Sediments were sectioned in $1 \mathrm{~cm}$ intervals to a depth of $10 \mathrm{~cm}$ and then in $2 \mathrm{~cm}$ intervals to the bottom of the core. Porosity was measured on 2 sediment cores from each station and is defined as the 'volume of water in the depth interval sampled/(total volume of water + sediment)'. Organic C and N were measured in 1992 to 1994 following carbonate removal. Chlorophyll and phaeopigments were measured (1994) in the surface $5 \mathrm{~cm}$ of sediment.

Estimating denitrification. A stoichiometric massbalance method was used to estimate denitrification. Two assumptions are involved: (1) the amount of organic matter decomposed within the sediments can be estimated from fluxes of decomposition end products across the sediment-water interface, and (2) the elemental (C:N:P:O) ratio of decomposing organic matter is known. The rate of decomposition and the elemental ratio of the material decomposed are used to calculate an expected $\mathrm{N}$ flux from the sediments. The expected $\mathrm{N}$ flux is compared to the measured flux of DIN from the sediments. The difference between expected and measured DIN flux is attributed to denitrification. It is assumed that the organic matter being decomposed has a $\mathrm{C}: \mathrm{N}$ stoichiometry between that of fresh algae (6.625:1, Parsons et al. 1984) and bulk organic matter of local sediments (10.41:1, see 'Results'). Sediment burial of organic matter is irrelevant to these calculations.

\section{RESULTS}

\section{Fluxes: temporal patterns}

Seasonal and year-to-year variations were observed at 4 stations: MB01, MB02, MB03, and MB05.

\section{Dissolved oxygen}

Oxygen uptake rates ranged from about 6.2 to $30.1 \mathrm{mmol} \mathrm{O}_{2} \mathrm{~m}^{-2} \mathrm{~d}^{-1}$ for Stns MB01, 02, 03, and 05 during 1992 to 1994 (Fig. 2, Table 3). Oxygen consumption tracked water temperature, being lowest in late winter, progressively increasing during summer, and reaching maximum rates in fall. There were no consistent differences among stations through July, but during late summer and fall the respiration at Stn MB05 (74 m) was lower than at the shallower stations (33 to $35 \mathrm{~m}$ ). Bottom-water temperatures were almost $5^{\circ} \mathrm{C}$ lower at MB05 than at the other stations during late summer/fall. The seasonal pattern of oxygen uptake was consistent from year to year for each of the stations. 

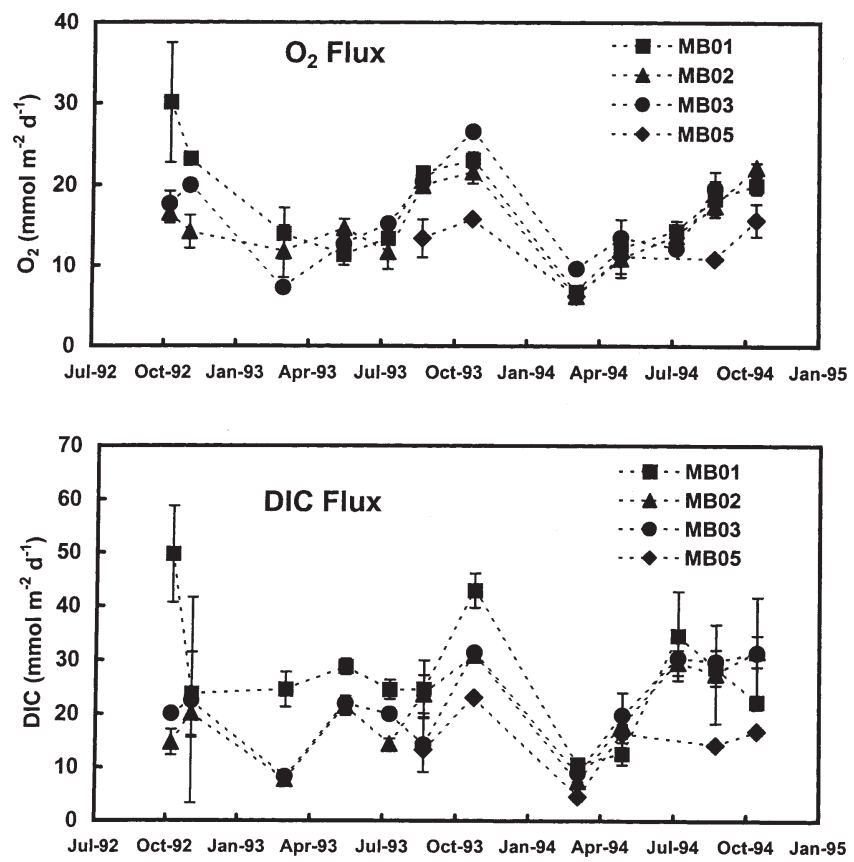

Fig. 2. Benthic $\mathrm{O}_{2}$ and DIC fluxes (means and $\pm \mathrm{SE}$ ) in Massachusetts Bay (Stns MB01, 02, 03) and Stellwagen Basin (Stn MB05)

Annual average rates of oxygen uptake were similar for Stns MB01, 02, 03, (14.8 $\mathrm{mmol} \mathrm{O}_{2} \mathrm{~m}^{-2} \mathrm{~d}^{-1}$ ) and varied little from year to year. Year-to-year variation was also minor at Stn MB05. The average rate of oxygen consumption was about $28 \%$ lower at MB05 (10.6 $\mathrm{mmol} \mathrm{O}_{2} \mathrm{~m}^{-2} \mathrm{~d}^{-1}$ ) than at the shallower stations.
Dissolved inorganic carbon

$\mathrm{TCO}_{2}$ fluxes ranged from about 4.5 to $49.7 \mathrm{mmol} \mathrm{C}$ $\mathrm{m}^{-2} \mathrm{~d}^{-1}$ over the period 1992 to 1994 for Stns MB01, 02, 03, and 05 (Fig. 2, Table 3). As with oxygen consumption, there was a clear seasonal pattern of DIC production, which was lowest in late winter and highest in late spring/early summer or later summer/early fall. On an annual basis, DIC production was similar at Stns MB01, 02, and 03, and between years. DIC production at Stn MB05 was about half that at Stns MB01, 02, and 03 (12.1 vs $21.4 \mathrm{mmol} \mathrm{C} \mathrm{m} \mathrm{m}^{-2} \mathrm{~d}^{-1}$ ).

DIC fluxes did not track bottom-water temperature as closely as did oxygen consumption. A late spring/ early summer peak in DIC flux probably reflects the benthic response to phytoplankton deposition in spring, while the late summer/fall peak in oxygen consumption may reflect the re-oxidation of reduced metabolic products produced earlier in the year. In general the RQ (respiratory quotient, $\mathrm{TCO}_{2}: \mathrm{O}_{2}$ ) was highest in spring/summer and decreased in fall. The annual average RQ was $>1$ for all stations, indicating a net storage of anaerobic products during the periods when we sampled.

\section{Dissolved inorganic nitrogen}

Sediments were always a source of inorganic nutrients for the overlying water. $\mathrm{NH}_{4}{ }^{+}$fluxes ranged from -0.03 to $4.04 \mathrm{mmol} \mathrm{m} \mathrm{m}^{2} \mathrm{~d}^{-1}$ and $\mathrm{NO}_{2}^{-}+\mathrm{NO}_{3}^{-}$fluxes ranged from -0.2 to $0.67 \mathrm{mmol} \mathrm{m}^{-2} \mathrm{~d}^{-1}$ at Stns MB01,

Table 3. Summary of metabolic fluxes measured between October 1992 and November 1994 in Massachusetts Bay and Stellwagen Basin. Units: mmol m${ }^{-2} \mathrm{~d}^{-1}$ except $\mathrm{N}_{2} \mathrm{O}$ and urea for which units are $\mu \mathrm{mol} \mathrm{m} \mathrm{m}^{-2} \mathrm{~d}^{-1}$. Reported are the maximum ranges observed during the study and the weighted annual averages calculated for 1993 and 1994. $\mathrm{n}=12$ for all variables at MB01, 02, and 03, except Si for which $\mathrm{n}=10 ; \mathrm{n}=6$ for all variable at MB05. nd: not determined, due to insufficient temporal coverage

\begin{tabular}{|c|c|c|c|c|c|c|c|c|}
\hline Station & $\mathrm{O}_{2}$ & DIC & $\mathrm{NH}_{4}^{+}$ & $\mathrm{NO}_{3}^{-}$ & $\mathrm{PO}_{4}{ }^{3-}$ & $\mathrm{Si}^{-}$ & $\mathrm{N}_{2} \mathrm{O}$ & Urea \\
\hline \multicolumn{9}{|l|}{ MB01 } \\
\hline Range & $6.8-30.1$ & $10.6-49.7$ & $-0.02-4.04$ & $-0.2-0.63$ & $0-0.49$ & $2.43-14.1$ & $-0.3-0.6$ & $-0.01-0.01$ \\
\hline 1993 Mean & 16.7 & 29.8 & 1.7 & 0.1 & 0.2 & 5.1 & 0.02 & nd \\
\hline 1994 Mean & 13.3 & 19.1 & 1.0 & 0.2 & 0.1 & 5.6 & 0.27 & 0.008 \\
\hline \multicolumn{9}{|l|}{ MB02 } \\
\hline Range & $6.2-22.2$ & $7.4-31.6$ & $0.1-2.3$ & $-0.1-0.5$ & $-0.01-0.2$ & $1.82-8.6$ & $-1.5-1.1$ & $-0.02-0.04$ \\
\hline 1993 Mean & 15.7 & 18.6 & 0.8 & 0.1 & 0 & 3.6 & -0.08 & nd \\
\hline 1994 Mean & 13.3 & 20.5 & 1.0 & 0.3 & 0.2 & 5.7 & 0.57 & 0.004 \\
\hline \multicolumn{9}{|l|}{ MB03 } \\
\hline Range & $7.3-26.5$ & $8.3-31.3$ & $0.4-2.0$ & $-0.1-0.67$ & $-0.03-0.5$ & $1.8-13.5$ & $-0.5-0.7$ & $-0.01-0.06$ \\
\hline 1993 Mean & 15.6 & 18.5 & 0.8 & 0.2 & 0.1 & 5.1 & 0.08 & nd \\
\hline 1994 Mean & 14.3 & 21.6 & 1.1 & 0.2 & 0.1 & 6.7 & 0.20 & 0.005 \\
\hline \multicolumn{9}{|l|}{ MB05 } \\
\hline Range & $6.2-15.8$ & $4.5-23.0$ & $-0.03-0.8$ & $0.1-0.5$ & $-0.03-0.2$ & $3.7-9.2$ & $-0.4-0.5$ & $-0.02-0.04$ \\
\hline 1993 Mean & nd & nd & nd & nd & nd & nd & 0.01 & nd \\
\hline 1994 Mean & 10.6 & 12.1 & 0.3 & 0.2 & 0.1 & 6.1 & 0.21 & 0.004 \\
\hline
\end{tabular}


02, 03, and 05 between 1992 to 1994 (Table 3, Fig. 3). Ammonium always dominated the inorganic $\mathrm{N}$ flux at Stns MB01, 02, and 03, but $\mathrm{NO}_{3}{ }^{-}$sometimes exceeded $\mathrm{NH}_{4}{ }^{+}$flux at the deeper station, MB05. DIN flux was similar at Stns MB01, 02, and 03, averaging $1.23 \mathrm{mmol}$ $\mathrm{N} \mathrm{m}{ }^{2} \mathrm{~d}^{-1}$ during 1993 to 1994 . The average flux at MB05 (0.5 mmol $\left.\mathrm{N} \mathrm{m}^{2} \mathrm{~d}^{-1}\right)$ was less than half that at the shallower stations. $\mathrm{NO}_{3}{ }^{-}$comprised about $15 \%$ of the total DIN flux at the shallower stations, but $40 \%$ at the deeper station. Seasonal patterns varied from year to year and from station to station. Fluxes were low in late winter at all stations each year, but the timing of peak fluxes varied. We occasionally observed 2 periods of elevated fluxes: late spring/early summer and late summer/fall (Fig. 3). The pattern of DIN and its components did not closely match that exhibited by $\mathrm{O}_{2}$ or DIC. There was greater interannual variability in DIN fluxes than in DIC and $\mathrm{O}_{2}$.

\section{Urea}

Urea fluxes were very low throughout the year, ranging from -20 to $60 \mu \mathrm{mol} \mathrm{m} \mathrm{m}^{-2} \mathrm{~d}^{-1}$ (Table 3). There was no apparent seasonal pattern to urea flux. Average annual urea nitrogen flux for Stns MB01, 02, and 03, was $6 \mu \mathrm{mol} \mathrm{N} \mathrm{m} \mathrm{N}^{-2} \mathrm{~d}^{-1}$, and for Stn MB05 it was only $4 \mu \mathrm{mol} \mathrm{N} \mathrm{m}^{-2} \mathrm{~d}^{-1}$. In comparison with DIN flux, urea flux was $<1 \%$ of the total $\mathrm{N}$ budget for any station.
Urea was not an important part of the nitrogen budget at these stations.

$$
\mathrm{N}_{2} \mathrm{O}
$$

$\mathrm{N}_{2} \mathrm{O}$ fluxes were consistently very low and variable over space and time (Table 3). Fluxes at Stns MB01, 02, 03 , and 05 ranged from a low of $-1.5 \mu \mathrm{mol} \mathrm{N} \mathrm{O} \mathrm{m}^{-2} \mathrm{~d}^{-1}$ to a high of $1.1 \mu \mathrm{mol} \mathrm{N}_{2} \mathrm{O} \mathrm{m}^{-2} \mathrm{~d}^{-1}$. Variability was high among replicate core incubations, as demonstrated by standard errors that were occasionally 50 to $100 \%$ of the mean. There were no consistent differences among stations over the 2 yr observation. Seasonal patterns were similar in 1993 and 1994. Fluxes were highest in late spring and late summer and lowest in winter and mid-summer. Over an annual cycle, $\mathrm{N}_{2} \mathrm{O}$ flux averaged across all stations was $0.16 \mu \mathrm{mol} \mathrm{N}_{2} \mathrm{O} \mathrm{m} \mathrm{m}^{-2} \mathrm{~d}^{-1} \cdot \mathrm{N}_{2} \mathrm{O}$ does not appear to be an important part of the nitrogen budget at these sites on the continental shelf, representing an even smaller percentage than urea.

\section{Phosphate}

Over an annual cycle, phosphate fluxes across the sediment-water interface ranged from -0.03 to $0.50 \mathrm{mmol} \mathrm{P} \mathrm{m}^{-2} \mathrm{~d}^{-1}$. Mean annual $\mathrm{PO}_{4}{ }^{3-}$ fluxes were highest at Stn MB01 (0.17 mmol $\left.\mathrm{P} \mathrm{m}^{-2} \mathrm{~d}^{-1}\right)$ and lowest
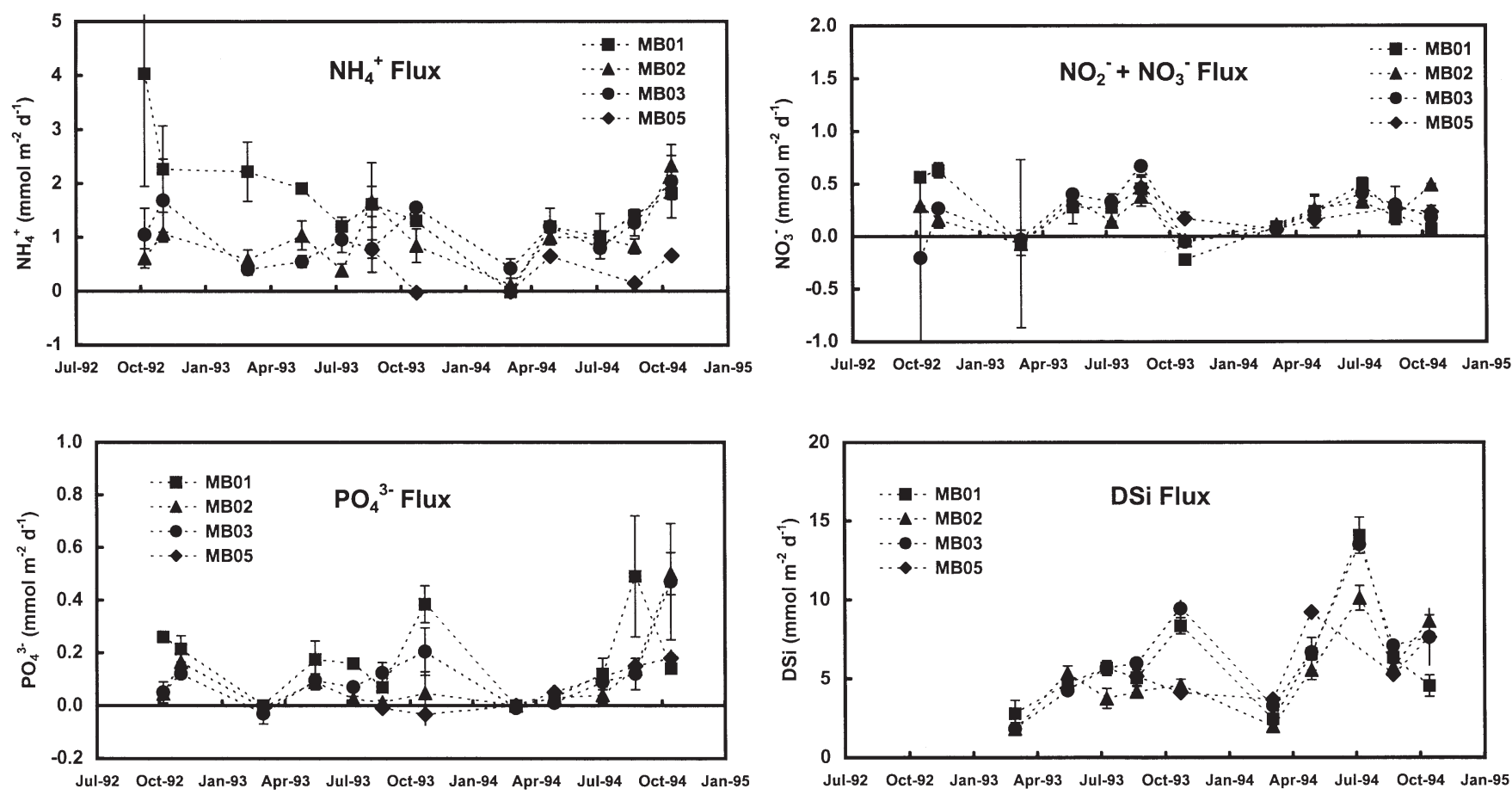

Fig. 3. Benthic nutrient exchange rates (means \pm SE) in Massachusetts Bay (Stns MB01, 02, 03) and Stellwagen Basin (Stn MB05) 
at MB05 (0.06 mmol P m $\left.\mathrm{m}^{-2} \mathrm{~d}^{-1}\right)$. There were often great differences between years. For example, the average flux at MB02 was $0.03 \mathrm{mmol} \mathrm{P} \mathrm{m} \mathrm{d}^{-1}$ in 1993 and 0.18 $\mathrm{mmol} \mathrm{P} \mathrm{m} \mathrm{m}^{-2}$ in 1994. Although there were no clear seasonal patterns at any of the stations, fluxes were always lowest in March and generally highest in late summer/early fall (Fig. 3).

Silica

Over an annual cycle, dissolved silicon fluxes ranged from 1.8 to $14.1 \mathrm{mmol} \mathrm{Si} \mathrm{m}{ }^{-2} \mathrm{~d}^{-1}$ (Table 3). Mean annual fluxes were similar for all the stations, averaging $5.3 \mathrm{mmol} \mathrm{Si} \mathrm{m}^{-2} \mathrm{~d}^{-1}$ at Stns MB01, 02, and 03, and $5.4 \mathrm{mmol} \mathrm{Si} \mathrm{m}^{-2} \mathrm{~d}^{-1}$ at MB05. There were no consistent differences between stations over the course of the season. Fluxes were consistently higher at all stations in 1994 than in 1993. Seasonal patterns often contrasted with patterns observed for $\mathrm{O}_{2}$, DIC or DIN, in that a mid-summer peak was common (Fig. 3). As with all other fluxes across the sediment-water interface, rates were lowest in late winter.

DIC:DSi flux ratios ranged from about 3.1 to $3.6: 1$ at Stns MB01, 02, and 03 and were 2.3:1 at MB05. The relatively high DSi fluxes may reflect the longer time constant of DSi dissolution and the redistribution and focusing of biogenic silicon particles following storm events especially in deeper water areas.

\section{Fluxes: spatial patterns}

Between 1990 and 1994, we measured benthic metabolism in late summer at several additional stations throughout Massachusetts and Cape Cod Bays. In combination with the seasonal studies at the 3 stations in Massachusetts Bay (MB01, 02, 03) and 1 station in Stellwagen Basin (MB05), this more extensive database enables us to discern broader spatial patterns in benthic metabolism (Fig. 4).

\section{Dissolved oxygen}

During late summer, oxygen uptake ranged from about 8 to $32 \mathrm{mmol} \mathrm{O}_{2} \mathrm{~m}^{-2} \mathrm{~d}^{-1}$ across all stations (Fig. 4). The highest rate was at Stn BS5 at a depth of $24 \mathrm{~m}$ and the lowest rate was at Stn MB07 at a depth of $76 \mathrm{~m}$. By region, rates of respiration decreased with increasing depth: Broad Sound (21.7 $\mathrm{mmol} \mathrm{O}_{2} \mathrm{~m}^{-2} \mathrm{~d}^{-1}$ ), followed by (30 to $35 \mathrm{~m}$ ) Massachusetts Bay (18.1 mmol $\mathrm{O}_{2} \mathrm{~m}^{-2} \mathrm{~d}^{-1}$ ), Cape Cod Bay (14.9 mmol $\mathrm{O}_{2} \mathrm{~m}^{-2} \mathrm{~d}^{-1}$ ) and finally the deep-water $(>70 \mathrm{~m})$ Stellwagen Basin $\left(10.1 \mathrm{mmol} \mathrm{O}_{2} \mathrm{~m}^{-2} \mathrm{~d}^{-1}\right)$. Very large differences in oxy- gen consumption were found between the 2 shallow water stations of Broad Sound (11 to $32 \mathrm{mmol} \mathrm{O}_{2} \mathrm{~m}^{-2}$ $\mathrm{d}^{-1}$ ). This range is as large as the entire range observed across all sites. We suspect that the high spatial variability observed in Broad Sound is due to the extremely patchy nature of the bottom. SCUBA divers observed a transition from sandy to cobble bottom within meters of where cores were collected.

\section{Dissolved inorganic carbon}

$\mathrm{TCO}_{2}$ fluxes ranged from about 9 to $39 \mathrm{mmol} \mathrm{CO}_{2}$ $\mathrm{m}^{-2} \mathrm{~d}^{-1}$ during late summer (DIC: Fig. 4). The spatial pattern of fluxes was similar to that observed for $\mathrm{O}_{2}$, with fluxes decreasing with increasing depth. Fluxes were highest in Massachusetts Bay $\left(27.1 \mathrm{mmol} \mathrm{m}^{-2}\right.$ $\mathrm{d}^{-1}$ ), and were substantially lower in Cape Cod Bay $\left(15.3 \mathrm{mmol} \mathrm{m}^{-2} \mathrm{~d}^{-1}\right)$ and Stellwagen Basin $(\sim 11.3 \mathrm{mmol}$ $\left.\mathrm{CO}_{2} \mathrm{~m}^{-2} \mathrm{~d}^{-1}\right)$. DIC fluxes were not measured in Broad Sound. DIC fluxes equaled or exceeded $\mathrm{O}_{2}$ consumption on all but 1 occasion.

\section{Dissolved inorganic nitrogen}

DIN flux was highest in Broad Sound (mean: $2.0 \mathrm{mmol} \mathrm{N} \mathrm{m}^{-2} \mathrm{~d}^{-1}$ ) and lowest (mean: $0.54 \mathrm{mmol} \mathrm{N} \mathrm{m}^{-2}$ $\left.\mathrm{d}^{-1}\right)$ in Stellwagen Basin $\left(\mathrm{NH}_{4}{ }^{+}, \mathrm{NO}_{2}{ }^{-}+\mathrm{NO}_{3}{ }^{-}\right.$: Fig. 4). It was intermediate in Massachusetts Bay (mean: $1.8 \mathrm{mmol} \mathrm{N} \mathrm{m}^{-2} \mathrm{~d}^{-1}$ ) and Cape Cod Bay (mean: $1.2 \mathrm{mmol}$ $\mathrm{N} \mathrm{m}^{-2} \mathrm{~d}^{-1}$ ). DIN flux was dominated by $\mathrm{NH}_{4}{ }^{+}$flux at all sites. $\mathrm{NH}_{4}{ }^{+}$flux was greatest at Stn BS5 in Broad Sound (>4 mmol $\mathrm{N} \mathrm{m}^{2} \mathrm{~d}^{-1}$ ) and decreased through Massachusetts Bay, Cape Cod Bay and finally Stellwagen Basin. The spatial pattern for $\mathrm{NO}_{3}{ }^{-}$flux contrasted greatly with that for $\mathrm{NH}_{4}{ }^{+}$, with $\mathrm{NO}_{3}{ }^{-}$being consumed in Broad Sound and released in the other regions. There was little difference in $\mathrm{NO}_{3}{ }^{-}$flux in the other regions. The relative importance of $\mathrm{NO}_{3}{ }^{-}$flux increased with increasing depth, contributing 0, 22, 35 and $44 \%$ of the total DIN flux into Broad Sound, into the medium-depth Massachusetts Bay sites, into Cape Cod Bay and into the deep water Stellwagen Basin sites respectively.

\section{Urea and $\mathrm{N}_{2} \mathrm{O}$}

Urea and $\mathrm{N}_{2} \mathrm{O}$ fluxes were very low at all stations with no discernible differences between stations. The average urea and $\mathrm{N}_{2} \mathrm{O}$ fluxes across all stations were 2.7 and $0.47 \mu \mathrm{mol} \mathrm{N} \mathrm{m}{ }^{-2} \mathrm{~d}^{-1}$ (data not shown). Relative to $\mathrm{NH}_{4}{ }^{+}$and $\mathrm{NO}_{3}{ }^{-}$fluxes, they are trivial components of the $\mathrm{N}$ budgets at any site in this part of the continental shelf of the Gulf of Maine. 

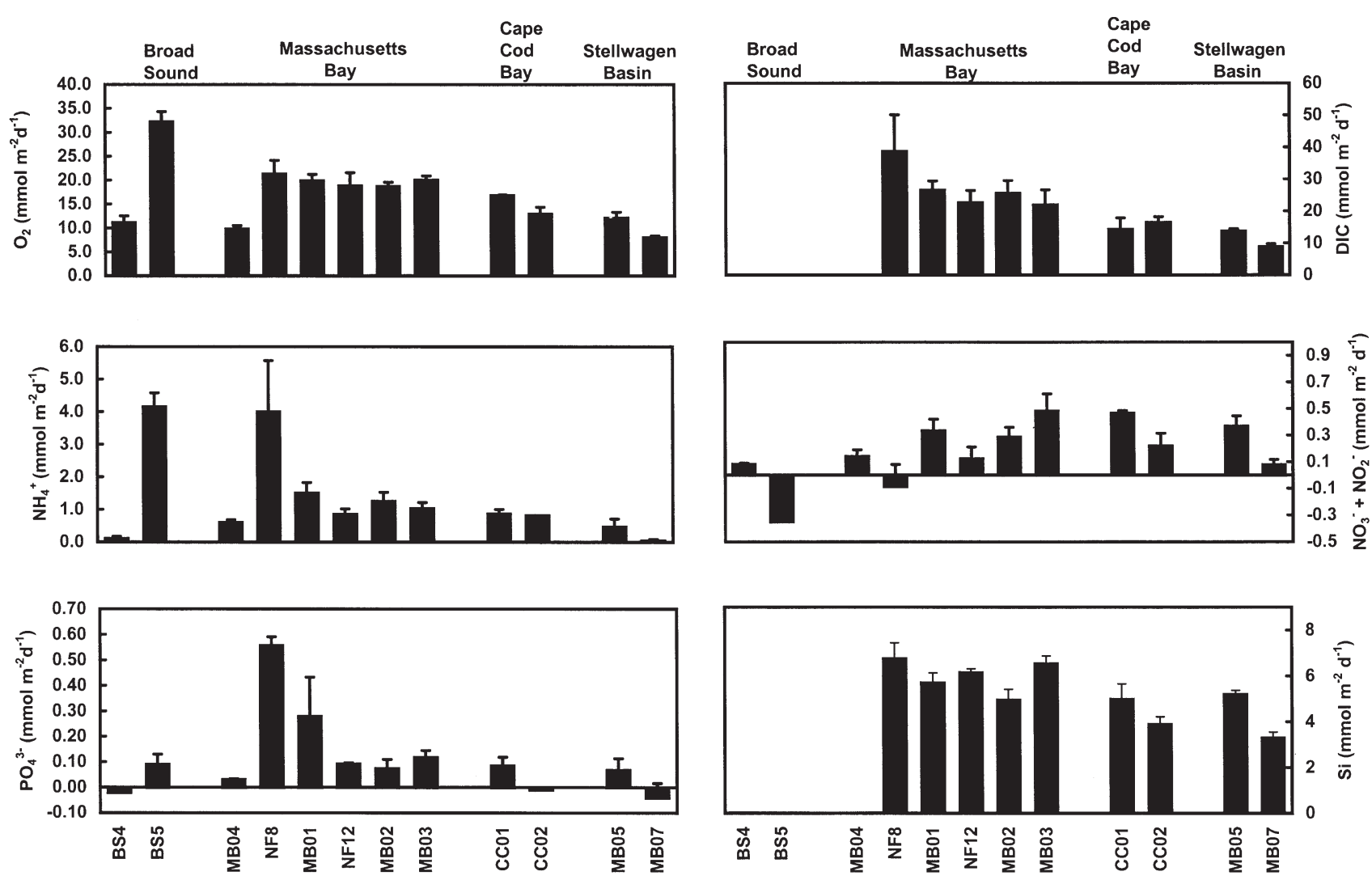

Fig. 4. Spatial pattern of benthic respiration $\left(\mathrm{O}_{2}\right.$ and DIC fluxes: means $\left.\pm \mathrm{SE}\right)$ and nutrient flux $\left(\mathrm{NH}_{4}{ }^{+}, \mathrm{NO}_{2}{ }^{-}+\mathrm{NO}_{3}{ }^{-}, \mathrm{PO}_{4}{ }^{3-}\right.$, and DSi: means + SE) during late summer. Station designations as in Table 1

Phosphate

During late summer there was a wide range in $\mathrm{PO}_{4}{ }^{3-}$ fluxes from site to site (Fig. 4). At several stations there was a slight uptake (BS4, CC02, MB07), while at others there was a release of up to $0.56 \mathrm{mmol} \mathrm{PO}_{4}{ }^{3-} \mathrm{m}^{-2} \mathrm{~d}^{-1}$ (at NF8). Most fluxes were $<0.14 \mathrm{mmol} \mathrm{m}^{-2} \mathrm{~d}^{-1}$, however. Averaged by region, $\mathrm{PO}_{4}{ }^{3-}$ fluxes were highest in the mid-depth Massachusetts Bay (averaging $0.18 \mathrm{mmol}$ P) lowest in Stellwagen Basin (0.015 mmol P) and intermediate in Broad Sound and Cape Cod Bay (averaging about 0.031 and $0.037 \mathrm{mmol} \mathrm{P} \mathrm{m} \mathrm{m}^{-2} \mathrm{~d}^{-1}$ respectively).

\section{Silica}

In late summer, DSi fluxes ranged from about $3.3 \mathrm{mmol} \mathrm{m}^{-2} \mathrm{~d}^{-1}$ at MB07 to $6.8 \mathrm{mmol} \mathrm{m}^{-2} \mathrm{~d}^{-1}$ at NF8 (Fig. 4). On average, fluxes were higher in mid-depth waters of Massachusetts Bay $\left(6 \mathrm{mmol} \mathrm{m}^{-2} \mathrm{~d}^{-1}\right)$ than in Cape Cod Bay (4.4 mmol m $\mathrm{m}^{-2} \mathrm{~d}^{-1}$ ) or Stellwagen Basin $\left(4.2 \mathrm{mmol} \mathrm{m}^{-2} \mathrm{~d}^{-1}\right)$.

DSi to DIC flux ratios decreased from about 4.55:1 in Massachusetts Bay to 3.33:1 and 2.94:1 in Cape Cod Bay and Stellwagen Basin. Lower DIC:DSi ratios in Cape Cod Bay and Stellwagen Basin than in Massachusetts Bay may indicate a greater importance of diatoms in the former areas. Other investigators noted an intense bloom of the diatom Asterionellopsis glacialis Lebour in late summer/early fall of 1993 in the deeper waters toward Stellwagen Basin (Kelly \& Doering 1997).

\section{Sediment and porewater constituents}

Sediment carbon and nitrogen

Sediment carbon and nitrogen content (Table 1) exhibited no obvious patterns spatially or temporally. Average $\mathrm{C}, \mathrm{N}$ and $\mathrm{C} / \mathrm{N}$ ratios for all stations over time were $1.68 \pm 1.03 \%, 0.20 \pm 0.13 \%$, and $10.41 \pm 1.72$ respectively. We suspect the lack of apparent spatial or temporal patterns reflects small-scale heterogeneity and sediment reworking and movement due to storms more than to biological activity in the water column or benthos.

$\mathrm{C}$ and $\mathrm{N}$ depth profiles measured in July 1994 revealed a trend of generally decreasing concentrations with increasing sediment depth to $13 \mathrm{~cm}$ (data not 
shown). $\mathrm{C} / \mathrm{N}$ ratios either remained constant with depth (Stellwagen Basin, MB05 and MB07) or increased with depth from about 10 to 12:1 to about 14 to 16:1 (Massachusetts Bay sites). This increase in the $\mathrm{C} / \mathrm{N}$ ratio may indicate humification of organic matter.

Sediment chlorophyll $a$ and phaeopigments

Sediment chlorophyll $a$ and phaeopigment levels, measured only during 1994, ranged from 0.65 to $5.11 \mu \mathrm{g} \mathrm{cm}^{3}$ and 2.34 to $22.93 \mu \mathrm{g} \mathrm{cm}^{3}$, respectively in the surface $5 \mathrm{~cm}$ of sediment (Table 1). Concentrations of chlorophyll $a$ and phaeopigments were lowest in late winter, prior to spring and summer phytoplankton blooms. There was little variation from station to station in March $\left(0.6\right.$ to $\left.0.9 \mu \mathrm{g} \mathrm{cm}^{3}\right)$. Peak chlorophyll a concentrations were in May at Stns MB01 and MB05, August for MB03, and October for MB02. Sediment pigment concentrations tended to be higher at the shallower $(30 \mathrm{~m})$ stations than at the deeper $(74 \mathrm{~m})$ station. Chlorophyll a inventories (to $5 \mathrm{~cm}$ ) ranged from $33 \mathrm{mg} \mathrm{m}^{-2}$ in winter to $255 \mathrm{mg} \mathrm{m}^{-2}$ during summer/fall. Phaeopigments were higher than chlorophyll $a$ at all times of the year, being on average 6 to 8 times greater. Considering the close proximity of Stns MB01, 02 and 03 to each other, the variability between stations most likely reflects a very patchy bottom distribution caused by particle focusing during settlement and by resuspension and lateral redistribution during storms.

\section{Biogenic silica}

The average biogenic silica content of sediments was about twice as high at MB05 $\left(\sim 0.24 \mathrm{mmol} \mathrm{Si} \mathrm{cm}^{-3}\right)$ than at MB01 $\left(\sim 0.14 \mathrm{mmol} \mathrm{Si} \mathrm{cm}^{-3}\right)$. There were slight increases in $\mathrm{Si}$ content over a $12 \mathrm{~cm}$ profile (data not shown).

\section{$\mathrm{pH}$}

Hydrogen ion concentrations ranged from $\mathrm{pH} 6.9$ to pH 7.9 in porewaters extracted seasonally during 1993 and 1994 from 3 Massachusetts Bay sites and 1 Stellwagen Basin site (MB01, 02, 03, and 05; data not shown). $\mathrm{pH}$ often decreased by up to 0.4 with increasing depth in the sediment.

Eh

For all stations, redox potentials were positive in the top few centimeters of sediment and decreased with increasing depth, tending to asymptote at about -50 to $-150 \mathrm{mV}$ by about $4 \mathrm{~cm}$ (Fig. 5). Eh profiles varied over time in several top centimeters of the surface, differing by up to $140 \mathrm{mV}$ on adjacent sampling dates. The depth at which the profile became negative also varied considerably from month to month. There were no apparent differences between stations that were consistent from one sampling to the next.

\section{Alkalinity}

Alkalinity values generally increased with increasing depth from about $2.3 \mathrm{mEq}$ at the surface to about 3 to $4 \mathrm{mEq}$ by $20 \mathrm{~cm}$. Values very rarely exceeded $5 \mathrm{mM}$ in sediments. There were no apparent seasonal or station-to-station patterns detected. As with Eh, alkalinity levels often fluctuated considerably between sampling dates.

\section{Sulfides}

Sulfides were seldom detected in the porewater from any of the stations examined (data not shown).

\section{Nutrients}

Nitrate was detected only in the surface $3 \mathrm{~cm}$ of sediment (data not shown). Values generally decreased from 4 to $10 \mu \mathrm{M}$ in the overlying water to $<0.5 \mu \mathrm{M}$ by $3 \mathrm{~cm}$.

Concomitant with the nitrate decrease with increasing depth was an increase in ammonium concentrations. Surface $\mathrm{NH}_{4}{ }^{+}$concentrations were generally 4 to $20 \mu \mathrm{M}$, and increased to 100 or $200 \mu \mathrm{M}$ by $20 \mathrm{~cm}$. On a few occasions, $\mathrm{NH}_{4}{ }^{+}$concentrations exceeded $400 \mu \mathrm{M}$. There were no consistent seasonal or spatial patterns other than that the sediments were always a source of ammonium for the overlying water column. As with Eh and alkalinity, porewater $\mathrm{NH}_{4}{ }^{+}$levels often changed considerably between sampling dates (Fig. 5).

Phosphate concentrations also increased with increasing depth (Fig. 5). Surface values were almost always below the limit of detection. Highest concentrations, which were generally found at the deepest depth investigated $(20 \mathrm{~cm})$, ranged from 50 to $100 \mu \mathrm{M}$. On several occasions, concentrations exceeded $150 \mu$ M. Replicate cores showed a good deal of variation, with maximum concentrations occasionally varying by $50 \%$. Depth profiles were not uniform over an annual cycle, rather there were considerable differences from sampling to sampling and from station to station. 

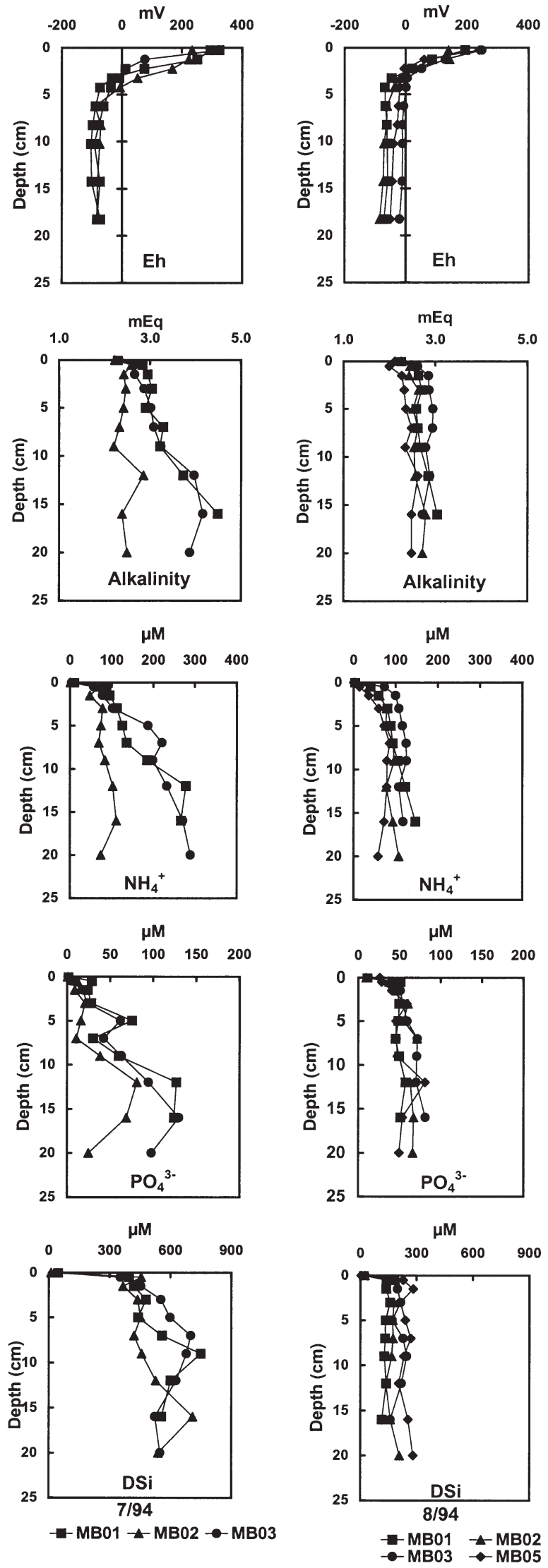

Fig. 5. Porewater profiles in July and August 1994
Dissolved silica (DSi or $\mathrm{Si}[\mathrm{OH}]_{4}$ ) concentrations exhibited the strongest concentration gradients of any of the nutrients examined (Fig. 5). Concentrations were always higher in sediments than in the overlying water, and increased substantially with increasing depth. Concentrations were considerably higher from March 1994 through July 1994, exceeding $500 \mu \mathrm{M}$ at depth. During late summer and fall 1994, concentrations returned to levels common throughout 1993. High concentrations probably reflect the large diatom bloom that occurred in fall 1993. As with the other porewater nutrients, there were no consistent spatial patterns in dissolved $\mathrm{Si}$ porewater profiles but there were dramatic temporal changes (Fig. 5).

\section{DISCUSSION}

There are few studies of benthic metabolism that have been conducted across several years and in multiple sites in any coastal environment, and none from the continental shelf. Our results are valuable in that they illustrate the variability that can be expected across temporal and spatial scales ranging from weeks to years and from meters to tens of kilometers. Knowledge of small-scale temporal and spatial variability is a prerequisite for discerning long-term trends that can result from increased nutrient loading to the coastal zone and global or regional climate change. Our temporal results show that variation exists across temporal and spatial scales and that it is different for the several benthic parameters we measured. Observations over many more years will be required to adequately address long-term phenomena. Federal courts have mandated continued monitoring of Boston sewage discharge; the resultant dataset for Massachusetts Bay should be invaluable.

We found relatively minor annual variation in several variables and enormous variation in others. The least interannual variation was observed for metabolism, in terms of both $\mathrm{O}_{2}$ consumption and DIC production. Between 1993 and 1994, there was typically less than a $25 \%$ difference in mean annual rates. $\mathrm{NH}_{4}{ }^{+}$and DSi fluxes were slightly more variable, with annual fluctuations on the order of 10 to $40 \%$. The other nutrients we examined, $\mathrm{NO}_{3}{ }^{-}$, urea, $\mathrm{N}_{2} \mathrm{O}$ and $\mathrm{PO}_{4}{ }^{3-}$, were extremely variable, with year-to-year differences in excess of $100 \%$. Interestingly, there were also differences in the years in which the various variables were highest. $\mathrm{O}_{2}$ and DIC fluxes were generally higher in 1993 than in 1994. In contrast, $\mathrm{NO}_{3}^{-}, \mathrm{DSi}$ and $\mathrm{N}_{2} \mathrm{O}$ fluxes were generally higher in 1994 than in 1993. Primary production was 32\% higher in 1993 than in 1994, due mainly to a large late summer bloom (Kelly \& Doering 1997). Thus respiration $\left(\mathrm{O}_{2}\right.$ and DIC flux $)$ 
appears to be more coupled to primary production than nutrient remineralization and flux.

Seasonal patterns were also found to vary from year to year and among the various constituents investigated. While seasonal patterns were very clear for metabolism $\left(\mathrm{O}_{2}\right.$ and DIC), and easily discernible for $\mathrm{NH}_{4}{ }^{+}$and $\mathrm{DSi}$, they were almost lacking for the others. The actual seasonal patterns, when present, varied from year to year. DIC, $\mathrm{NH}_{4}{ }^{+}$and DSi had 2 periods of enhanced flux in 1993 (spring and fall), but only a mid-summer peak in 1994. For $\mathrm{NO}_{3}{ }^{-}$, urea, $\mathrm{N}_{2} \mathrm{O}$ and $\mathrm{PO}_{4}{ }^{3-}$, rates were consistently lowest in late winter (March), but the timing of highest fluxes could be in any season. In 1994, the seasonal pattern of primary production was bimodal and reflected that for DIC, $\mathrm{NH}_{4}{ }^{+}$and $\mathrm{DSi}$ fluxes from the previous year (Kelly \& Doering 1997).

Spatially, we noted a common pattern of decreasing benthic flux rates with increasing depth or distance from Boston Harbor. While the differences between regions were not necessarily large, the trend was for $\mathrm{O}_{2}, \mathrm{DIC}, \mathrm{NH}_{4}{ }^{+}$and DSi to be highest in Broad Sound and to decrease through Massachusetts Bay, Cape Cod Bay, and finally to Stellwagen Basin. However, we also found that variations within relatively small areas, such as Broad Sound, can be as great as between large areas such as between Broad Sound and Stellwagen Basin.

It is not clear why there are differences in the temporal variability of nutrient flux versus metabolism. It is likely that aperiodic events such as storms influence nutrient flux to a greater extent than microbial metabolism and therefore $\mathrm{O}_{2}$ consumption. Storms can flush accumulated porewater nutrients from sediments (Marinelli et al. 1998), thereby lowering diffusion and hence nutrient flux. At the same time, mixing of sediments can provide fresh organic matter to microbes, thereby sustaining respiratory consumption of $\mathrm{O}_{2}$ (Hopkinson 1987).

\section{Comparisons with other coastal and marine systems}

Rates of benthic respiration and nutrient flux from sediments to the overlying water were of the same order of magnitude as rates reported for similar coastal environments. For the stations for which we have annual flux estimates (MB01, 02, 03, 05), annual metabolism ranged from 12.1 to $29.8 \mathrm{mmol} \mathrm{C} \mathrm{m}^{-2} \mathrm{~d}^{-1}$ (Stns MB05 and MB01 respectively). Sediments were sources of inorganic N. Annual average DIN fluxes ranged from 0.5 to $1.8 \mathrm{mmol} \mathrm{N} \mathrm{m}^{-2} \mathrm{~d}^{-1}$ (Stns MB05 and MB01). These rates were similar to those observed in other shelf environments, such as La Jolla Bight, California (Hartwig 1976), Buzzards Bay, Massachusetts
(Rowe et al. 1975), the North Sea (Billen 1978), the Middle Atlantic Bight (Rowe et al. 1988), the South Atlantic Bight (Marinelli et al. 1998), and the eastern North Pacific (Devol \& Christensen 1993). The rates were lower than those generally observed in shallow and more productive estuarine environments such as Boston Harbor (Giblin et al. 1997), Narragansett Bay Rhode Island (Nixon 1981), Neuse River estuary, North Carolina (Fisher et al. 1982), and Patuxent River estuary, Maryland (Boynton et al. 1980). On the other hand, they were much higher than rates commonly found in the deep ocean (e.g., North Atlantic Deep: Smith et al. 1978).

For all stations, the flux of DIN was dominated by $\mathrm{NH}_{4}{ }^{+}$. The importance of $\mathrm{NO}_{3}{ }^{-}$fluxes relative to $\mathrm{NH}_{4}{ }^{+}$ increased with increasing depth. In late summer, the relative importance of $\mathrm{NO}_{3}{ }^{-}$fluxes increased from 0 to $44 \%$ of total DIN flux between Broad Sound and Stellwagen Basin. The relative importance increased from 15 to $40 \%$ between Massachusetts Bay and Stellwagen Basin on an average annual basis. As there was little or no spatial pattern evident for $\mathrm{NO}_{3}{ }^{-}$flux rates, the pattern of relative importance is attributable largely to a decrease in $\mathrm{NH}_{4}{ }^{+}$flux with increasing depth. That ammonium dominates the inorganic $\mathrm{N}$ flux appears to be the rule, but there have been reports in the literature of $\mathrm{NO}_{3}{ }^{-}$flux actually exceeding $\mathrm{NH}_{4}{ }^{+}$flux, e.g. for Kiel Bight and the North Sea (Billen 1978, Balzer 1984). Both these sites are relatively deep coastal environments. It has been suggested that DIN flux is reduced, overlying water $\mathrm{NO}_{3}{ }^{-}$is consumed, and most remineralized $\mathrm{N}$ is denitrified in highly productive deep-water systems, such as those found in western US continental shelf and slope systems (Bender et al. 1989, Devol \& Christensen 1993). This scenario does not describe our system: we observe little $\mathrm{NO}_{3}{ }^{-}$consumption. However, similar processes can explain the pattern of increased relative importance of $\mathrm{NO}_{3}^{-}$efflux with increasing water depth that we found. Lower rates of benthic metabolism further offshore should allow increased oxygen penetration into sediments that could thereby enhance rates of nitrification.

Annual phosphate fluxes ranged from 0.06 to $0.17 \mathrm{mmol} \mathrm{P} \mathrm{m}^{-2} \mathrm{~d}^{-1}$ (Stns MB05 and MB01). The literature suggests that there is more variability in $\mathrm{PO}_{4}{ }^{3-}$ flux than in any of the other commonly measured constituents, ranging from sites with P uptake (North Carolina estuaries: Fisher et al. 1982) to sites with substantial P release (e.g., $1.2 \mathrm{mmol} \mathrm{P} \mathrm{m} \mathrm{m}^{-2} \mathrm{~d}^{-1}$ in Cap Blanc, Africa: Rowe et al. 1977). Average annual silicate fluxes ranged from 3.96 to $6.7 \mathrm{mmol} \mathrm{Si} \mathrm{m}{ }^{-2} \mathrm{~d}^{-1}$, being lowest at Stn MB02 and highest at Stn MB03. These rates are lower than summer rates $\left(15.3 \mathrm{mmol} \mathrm{Si} \mathrm{m}^{-2}\right.$ $\mathrm{d}^{-1}$ ) measured in a productive mid-shelf site in Washington State (Devol \& Christensen 1993). 


\section{Relative rates of $\mathrm{C}, \mathrm{O}, \mathrm{N}$, and $\mathrm{P}$ flux}

Sediment organic matter decomposition is traditionally measured by the rate of sediment oxygen uptake. However, when oxygen is not the terminal electron acceptor of respiration, oxygen-based measures of decomposition can be underestimates. $\mathrm{CO}_{2}$ production provides another measure of decomposition that is not affected by terminal electron acceptor. The degree to which respiration is underestimated by oxygen depends on the fate of the reduced endproducts of anaerobic respiration. If the endproducts are ultimately reoxidized, oxygen accurately measures respiration. If the endproducts are stored in the sediments or released to the overlying water prior to being reoxidized, then respiration is underestimated by oxygen consumption. Oxygen-based estimates of respiration do not provide the true temporal pattern when there are lags between reduced endproduct production, storage and reoxidation. The ratio of $\mathrm{CO}_{2}$ to $\mathrm{O}_{2}$ fluxes (respiratory quotient, RQ) gives some indication of the relative importance and timing of oxic and anoxic decomposition.

Rates of oxygen consumption were lower than the release of inorganic carbon at nearly all sites and times (Fig. 6). The RQ varied over time and between stations, ranging from as low as 0.7:1 (Stn MB02 in March 1993 and MB03 in August 1993) to 2.5:1 (at Stn MB01 in May 1993). In 1993, there were 2 periods of elevated RQ (May and October), and in 1994 there was only 1 period (July). On an annual basis, the difference between oxygen- and carbon-based estimates of respiration was least at Stn MB05 (RQ 1.14:1) and greatest at Stn MB01 (RQ 1.63:1). In other studies where both $\mathrm{O}_{2}$ and DIC have been measured, RQ is often greater than 1. For example, Dollar et al. (1991) found that DIC fluxes were about $30 \%$ greater than $\mathrm{O}_{2}$ fluxes in Tomales Bay. In Boston Harbor, annual average DIC fluxes exceeded oxygen uptake at 2 stations in all 3 study years, with RQs ranging from 1.2 to 2.0 (Giblin et al. 1997).

That DIC release almost always exceeded $\mathrm{O}_{2}$ consumption suggests storage of reduced endproducts, such as $\mathrm{FeS}$ or $\mathrm{FeS}_{2}$. However, we have insufficient data to determine whether reduced endproducts are stored on an annual basis. There is the possibility that material stored during the March to November period is reoxidized or flushed from the system during midwinter when strong northeast storms are most common.

The accumulation or flux of alkalinity can be used to determine if large amounts of sulfide are being oxidized or stored (Hopkinson et al. 1999). Aerobic respiration of carbon neither produces nor consumes alkalinity. Sulfate reduction produces $1 \mathrm{~mol}$ of alkalinity for each mol of carbon oxidized. Sulfide oxidation consumes $1 \mathrm{~mol}$ of alkalinity for each mol of oxygen used. Alkalinity profiles from all stations demonstrate the importance of anaerobic metabolism and the storage of reduced endproducts of metabolism. Annual average alkalinity fluxes ranged from -0.13 to $3.21 \mathrm{mmol} \mathrm{m}^{-2}$ $\mathrm{d}^{-1}$ for Stns M01, 02, 03, and 05 (data not shown). How-
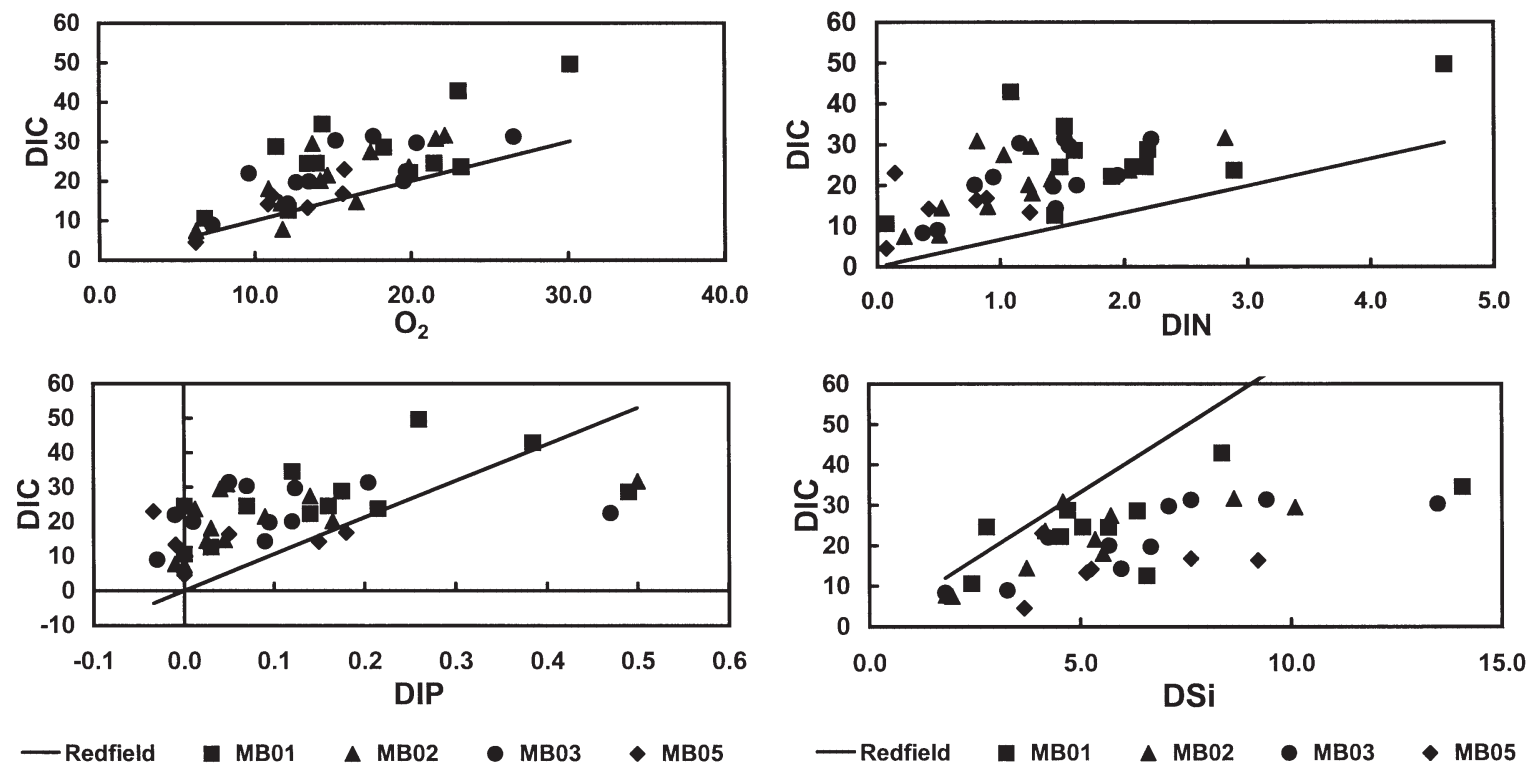

Fig. 6. Stoichiometry of DIC, DIN, $\mathrm{PO}_{4}{ }^{3-}$ (三 DIP), and DSi fluxes from seasonal studies in Massachusetts Bay (MB01, 02, 03) and Stellwagen Basin (MB03). For reference, Redfield stoichiometry for fresh plankton is shown as the line in each graph. DIC:DSi line is based on diatoms, which have a 1:1 DIN/DSi relation. All units are $\mathrm{mmol} \mathrm{m}^{-2} \mathrm{~d}^{-1}$ 
ever, $\mathrm{O}_{2}$ measures of respiration underestimated DIC measures by 17 to $40 \%$ or 2.63 to $9.9 \mathrm{mmol} \mathrm{m}^{-2} \mathrm{~d}^{-1}$ for these same stations. The alkalinity fluxes do not fully account for the discrepancy between $\mathrm{O}_{2}$ - and DICbased estimates of respiration. It is probable that the calculated diffusive fluxes underestimate true fluxes, as advection and bioturbation are neglected in diffusive flux calculations (see Hopkinson 1987).

Whereas DIC fluxes should be an accurate measure of total carbon decomposition, carbonate dissolution or precipitation can affect DIC dynamics. McNichol et al. (1988), using information on $\delta^{13} \mathrm{C}$ distribution, found that carbonate dissolution enhanced DIC fluxes by $2 \%$ during spring in Buzzards Bay, Massachusetts, but that dissolution was unimportant the rest of the year. We evaluated the possibility that calcium carbonate dissolution inflated estimates of respiratory DIC production by examining $\mathrm{Ca}^{2+}$ fluxes in several cores (data not shown). We did not detect a calcium flux to the overlying water at the 2 sites at which it was measured during October of 1993, suggesting that carbonate dissolution was not the major factor contributing to the excess DIC flux.

Relative rates of DIC, $\mathrm{PO}_{4}{ }^{3-}$, DIN and DSi release fluctuated considerably through time and space. Carbon to phosphorus flux ratios indicate strong phosphate retention by the sediments at most sites throughout the year (Fig. 6). Phosphate fluxes were often zero or even directed into sediments during all but the highest rates of respiration. Average annual C/P flux ratios ranged from 136 to 595:1, which are higher than predicted by the 106:1 Redfield ratio (Redfield 1958). It is quite likely that the efflux of remineralized phosphate was controlled in the surface oxidized layer by sorption with iron oxyhydroxides (Patrick \& Khalid 1974).

Dissolved silicon fluxes were high relative to other metabolic and nutrient parameters. This is reflected by low DIC to DSi flux ratios (averaging 3.9:1 across Massachusetts Bay and Stellwagen Basin), which are less than half as high as expected (Fig. 6). Diatoms have similar N and Si requirements (Brzezinski 1985), thus we would expect DIC:DSi ratios of about 7:1 only if diatoms made up the entire phytoplankton population. As diatoms represent only a component of the overall phytoplankton community, the flux ratio could be expected to be even higher. Undoubtedly, a combination of processes contribute to the high DSi fluxes. Probably of primary importance is the focusing and accumulation of biogenic silica-rich matter into depositional areas following major resuspension events such as those that occur during winter. The deposited material is likely to be silicon-rich because biogenic silica dissolution has a time constant that is long relative to the decomposition of fresh phytoplankton detritus (Conley et al. 1993). Remineralization of these deposits, which have already experienced a decline in organic matter quality due to previous decomposition, is likely to contribute to high DSi fluxes.

The ratio of DIC to DIN fluxes was high, ranging from about 8 to 160 for Stns MB01, 02, 03, and 05 (Fig. 6). On an annual basis, C:N was highest at the deep station, MB05 (25:1) and lowest at the shallower stations $(17: 1)$. As there was no indication of preferential storage of $\mathrm{N}$ in sediments, we attribute the low $\mathrm{N}$ fluxes to coupled nitrification and denitrification. That the DIC:DIN flux anomaly was highest in the deepest station suggests that the relative importance of coupled nitrification-denitrification is higher there. This pattern was evident in the spatial data as well, with the average DIC:DIN being 15:1 versus 23:1 in the Massachusetts Bay and Stellwagen Bank areas, respectively.

\section{Denitrification}

Denitrification was a major component of the benthic $\mathrm{N}$ cycle (Fig. 7). Denitrification rates were similar at MB01, 02, and 03 and higher over an annual period (0.8 to $1.9 \mathrm{mmol} \mathrm{N} \mathrm{m}^{-2} \mathrm{~d}^{-1}$ ) than in Stellwagen Basin ( 0.7 to $1.3 \mathrm{mmol} \mathrm{N} \mathrm{m} \mathrm{N}^{-2}$ ). However, a greater percentage of organic nitrogen remineralized by the benthos was denitrified at the deep-water site (58 to $72 \%$ ) than at the shallower Massachusetts Bay sites (38 to $60 \%$ ). Our range of denitrification rates reflects our assumption about the C:N of organic matter undergoing decomposition: 6.6:1 based on fresh phytoplankton or 10.4:1 based on bulk sediment C:N. Annual variation for the Massachusetts Bay stations was relatively small, on the order of 6 to $34 \%$. Seasonal patterns were similar for the Massachusetts Bay and Stellwagen stations, but varied between 1993 and 1994. In both years denitrification was minimal in March. In 1993 there were 2 periods of enhanced denitrification, spring and fall, whereas in 1994 denitrification was highest during mid-summer.

Estimates of denitrification based on the late summer spatial dataset suggest that denitrification varies along a depth and perhaps enrichment gradient. Denitrification was highest in Massachusetts Bay (0.8 to $2.3 \mathrm{mmol}$ $\left.\mathrm{N} \mathrm{m}^{-2} \mathrm{~d}^{-1}\right)$, followed by Stellwagen Basin and Cape Cod Bay (0.6 to $1.2 \mathrm{mmol} \mathrm{N} \mathrm{m}^{-2} \mathrm{~d}^{-1}$ and 0.3 to $1.1 \mathrm{mmol}$ $\mathrm{N} \mathrm{m}^{-2} \mathrm{~d}^{-1}$ ).

The denitrification rates we measured for the Massachusetts Bay continental shelf are at the lower end of the range of estimates for other estuarine and coastal marine sediments (Seitzinger 1988, Devol \& Christensen 1993). In more productive systems, such as eutrophic estuarine and continental shelves experiencing upwelling, denitrification rates are typically higher. 
Massachusetts Bay

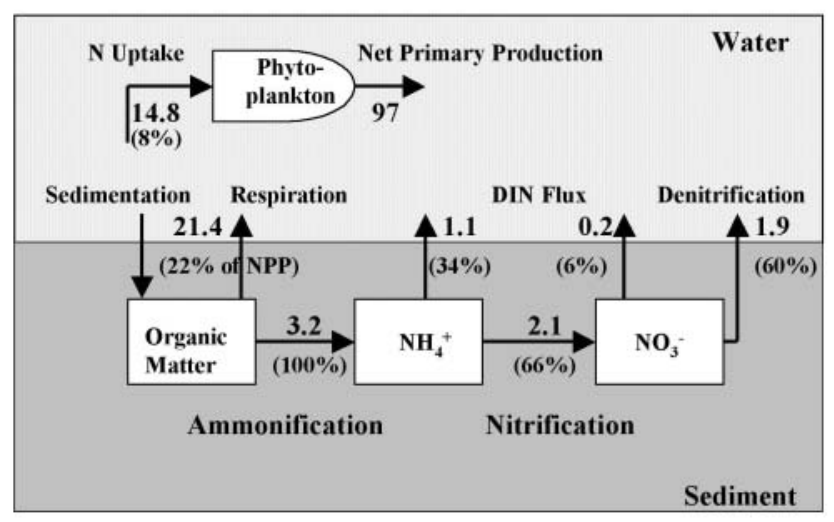

Stellwagen Basin

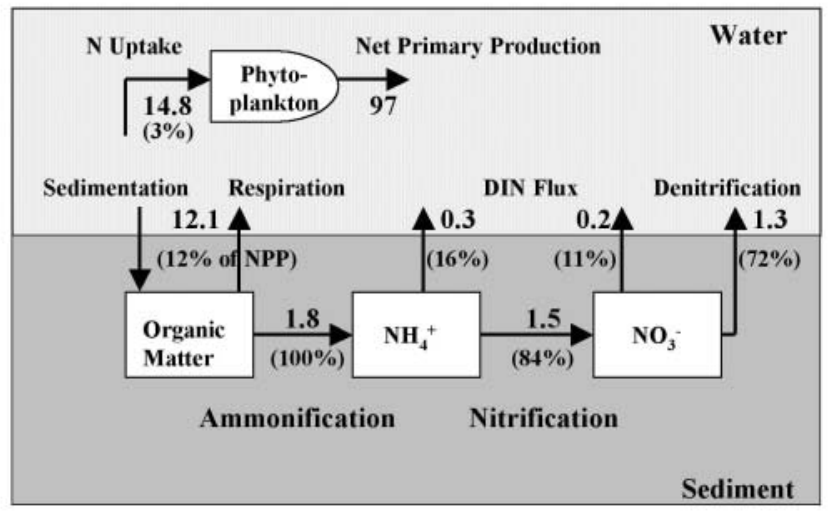

Fig. 7. Nitrogen cycle for Massachusetts Bay (ca $30 \mathrm{~m}$ deep) and Stellwagen Basin (ca $75 \mathrm{~m} \mathrm{deep).} \mathrm{Units} \mathrm{are} \mathrm{mmol} \mathrm{N} \mathrm{m}^{-2} \mathrm{~d}^{-1}$ except for net primary production and respiration, which are mmol $\mathrm{C} \mathrm{m}^{-2} \mathrm{~d}^{-1}$. Numbers in parentheses indicate percentage of remineralized $\mathrm{N}$ that follows the various pathways. Also shown is percentage of overlying water primary production that is respired by the benthos and percentage of phytoplankton $\mathrm{N}$ requirements that are met by benthic DIN flux

Whereas the rate of denitrification was not high, the percentage of organic $\mathrm{N}$ remineralized that was denitrified was (Fig. 7). In Massachusetts Bay, about $60 \%$ of remineralized N (based on DIC flux and 6.6:1 C/N stoichiometry) was denitrified. An even greater percentage was denitrified in deeper water: at Stn MB05 about $72 \%$ was denitrified. Thus $\mathrm{N}$ flux associated with denitrification was greater than the exchange of DIN across the sediment-water interface. These estimates of the relative importance of denitrification in the $\mathrm{N}$ cycle of a benthic marine system are in the upper range of most reports in the literature. In most coastal systems, Seitzinger (1988) reported that 20 to $70 \%$ of remineralized $\mathrm{N}$ is denitrified. However, in a compilation of several continental shelf systems where both denitrification and remineralization were measured, denitrification averaged nearly $75 \%$ of the total $\mathrm{N}$ remineralization (Seitzinger \& Giblin 1996), in agreement with our observations.

The pattern of denitrification in the presence of $\mathrm{NO}_{3}{ }^{-}$efflux from the sediments indicates that denitrification was supported by the coupled process of nitrification-denitrification. $\mathrm{NO}_{3}{ }^{-}$levels in the overlying water were never high $(<7.5 \mu \mathrm{M})$ and only infrequently was $\mathrm{NO}_{3}{ }^{-}$consumed. Oxygen concentrations on the other hand were high (always $>68 \%$ saturation). That such a large percentage of remineralized $\mathrm{N}$ was denitrified and that there was little evidence of direct denitrification (consumption of $\mathrm{NO}_{3}^{-}$from the overlying water) indicate that conditions were near optimal for coupled nitrification-denitrification. Factors that promote strong coupling between nitrification and denitrification include ample organic substrate supply (Cavari \& Phelps 1977, Slater \& Capone 1987), optimal redox conditions in the surface $3 \mathrm{~cm}$ for nitrification, closely spaced microenvironments (Jenkins \& Kemp 1984) optimal for nitrification and denitrification, and optimal porewater movement from infaunal burrow ventilation (Grundmanis \& Murray 1977, Sørensen 1978, Chatar-paul et al. 1980, Henriksen et al. 1980) and wave or current-induced advection. The lack of sulfides in our porewaters may further contribute to high nitrification-denitrification rates, since sulfide has been shown to inhibit nitrification in other studies (Joye \& Hollibaugh 1995).

The relative importance of direct and coupled denitrification differs in various shelf systems. In low oxygen, highly productive shelf systems such as along Washington State, direct denitrification is much more important than in the Gulf of Maine. Devol \& Christensen (1993) found that $40 \%$ of denitrification was directly supported by nitrate uptake from the overlying water. In productive systems with low bottom-water DO, sediments can actually be a net sink for inorganic $\mathrm{N}$, consuming more $\mathrm{NO}_{3}^{-}$than DIN released. Direct denitrification is promoted by high organic matter sedimentation rates, active macrofaunal irrigation, and low $\mathrm{O}_{2}$ and high $\mathrm{NO}_{3}{ }^{-}$concentrations in the overlying water (Devol \& Christensen 1993). Our results suggest that sediments on continental shelves with less productive surface waters (low organic matter sedimentation rates) and with high $\mathrm{O}_{2}$ concentrations in the overlying water are also important sites of denitrification, but the process is driven by a different mechanism, coupled nitrification-denitrification. Attempts to budget the $\mathrm{N}$ cycle and denitrification of continental shelves must consider the variety of conditions encountered on continental shelves and must base extrapolations on carbon input rate, sediment irrigation, and bottom water $\mathrm{DO}$ and $\mathrm{NO}_{3}{ }^{-}$concentrations. 
Direct measurements of denitrification were conducted concomitantly with many of our measurements of benthic metabolism and nutrient flux (Kelly \& Nowicki 1992, Nowicki et al. 1997). While differences between direct and stoichiometric measures of denitrification were often large at any single station and time, the average annual rates determined by direct measurements fell within our range of estimates calculated with variable sediment C:N stoichiometry. For example, the average annual rate of denitrification for Stns MBO1, 02 and 03 in 1993 measured directly was $1.03 \mathrm{mmol} \mathrm{N}$ $\mathrm{m}^{-2} \mathrm{~d}^{-1}$, whereas stoichiometrically calculated rates were between 0.83 and $2.06 \mathrm{mmol} \mathrm{N} \mathrm{m}^{-2} \mathrm{~d}^{-1}$.

\section{Controls on respiration}

Benthic respiration was positively but nonlinearly related to bottom-water temperature. Temperature accounted for 84 and $58 \%$ of the variance in $\mathrm{O}_{2}$ consumption and DIC production respectively, at Stns MB01, 02, 03, and $05\left(\mathrm{r}^{2}=0.84,0.58\right.$; log-transformed data; $\mathrm{p}<0.01)$. Temperature also accounted for a substantial amount of the variance in oxygen consumption measured at the 12 stations across the spatial gradient in late summer, accounting for $71 \%$ of the variance $\left(r^{2}=0.71, p<0.01\right)$.

We found no significant relation between organic $\mathrm{C}$ or total $\mathrm{N}$ content of the sediments and respiration for either the temporal or spatial datasets. This indicates that sediment organic content does not reflect organic supply rate, to which respiration should be closely related.

We found very strong relations between chlorophyll $a$, phaeopigments and total pigment (chlorophyll a plus phaeopigments) and the rate of respiration, especially DIC production. For the temporal dataset, total pigments accounted for $82 \%$ of the variance in DIC production and $56 \%$ in $\mathrm{O}_{2}$ consumption $\left(\mathrm{r}^{2}=\right.$ 0.82, 0.56; log-transformed data; $p<0.01)$. Algal pigment content may be an appropriate indicator of organic matter input to sediments. In open-water marine systems, the primary organic matter input to the benthos is derived from phytoplankton.

Thus, temperature accounted for the largest amount of the variance in $\mathrm{O}_{2}$ consumption while pigments accounted for the largest amount of variance in DIC production. Multiple regressions with temperature and pigments accounted for little more of the variance (i.e. only 1 to $2 \%$ above single-factor analysis).

\section{Controls on nutrient release}

The fluxes of inorganic nitrogen and phosphorus (DIN and $\mathrm{PO}_{4}{ }^{3-}$ ) were significantly and positively related to respiration (see Fig. 6) and temperature but not to sediment organic content or sediment redox conditions. A large percentage of the variability was related to organic matter degradation as measured by DIC flux, accounting for 46 and $38 \%$ of the temporal and spatial differences for DIN and $\mathrm{PO}_{4}{ }^{3-}$ flux respectively $\left(\mathrm{r}^{2}=0.46\right.$, $\left.\mathrm{df}=42 ; \mathrm{r}^{2}=0.38, \mathrm{df}=42\right)$. The relation with temperature was not as strong, but still accounted for 20 and $32 \%$ of the variance in nutrient flux $\left(\mathrm{r}^{2}=\right.$ $0.20, \mathrm{df}=42 ; \mathrm{r}^{2}=0.32, \mathrm{df}=42$ ). That we could account for less than $46 \%$ of the temporal variance suggests that additional factors exert an important influence on the exchange of remineralized nutrients across the sediment-water interface.

Respiration is a measure of organic matter decomposition and nutrient remineralization. Whereas the production of inorganic nutrients should be directly related to respiration, the release of nutrients from sediments to the overlying water might not be. Diffusive losses of nutrients are proportional to concentration gradients, which take time to develop. Nutrients can be trapped in mineral forms. Inorganic $\mathrm{N}$ can be nitrified and denitrified. Nutrients can also be flushed from sediments by macrofaunal irrigation, storms or porewater advection (Aller \& Yingst 1985, Hopkinson 1987, Marinelli et al. 1998). Our porewater profiles show how rapidly porewater nutrient concentrations change over time, suggesting the importance of sediment flushing (Fig. 5). However, we lack sufficient information to determine the extent to which these rapid changes were due to macrofaunal irrigation, storms or advective flushing (e.g. Martin \& Banta 1992, Devol \& Christensen 1993).

\section{Role of benthos in a continental shelf system}

Based on the annual average rate of organic matter decomposition as measured by DIC production, the benthos degrades from 20 to $24 \%$ of primary production (88 to $107 \mathrm{mmol} \mathrm{C} \mathrm{m}{ }^{-2} \mathrm{~d}^{-1}$ : Kelly \& Doering 1997) in the Massachusetts Bay region, where water depths are about 30 to $35 \mathrm{~m}$ (average of MB01, 02, and 03). In Stellwagen Basin, benthic metabolism (MB05) is equivalent to $11-14 \%$ of primary production (see Fig. 7). Numerous empirical models have been developed to relate vertical carbon flux to primary productivity and depth. In general, the higher the production and the shallower the water column, the greater the amount of photosynthetically fixed carbon that reaches the sediment. Using an average of several vertical C flux models (see Bishop 1989), the predicted $\mathrm{C}$ flux in 35 and $75 \mathrm{~m}$ of water, with a productivity of $427 \mathrm{~g} \mathrm{C} \mathrm{m}^{-2} \mathrm{yr}^{-1}$ (average from Kelly \& Doering 1997) is 200 and $107 \mathrm{~g} \mathrm{C} \mathrm{m}^{-2} \mathrm{yr}^{-1}$, or 47 and $25 \%$ 
of production respectively. The rates of benthic metabolism in these regions are much lower than the predicted C flux. Assuming organic matter standing stocks are at equilibrium, these results suggest that $\mathrm{C}$ deposition is less than expected. This is consistent with the results of Seitzinger \& Giblin (1996), who found that the average sediment oxygen demand of 17 continental shelf stations in the North Atlantic was $16.4 \%$ of the overlying primary production. Hopkinson (1985) and Martin et al. (1987) have shown that vertical C flux is often relatively lower in shallow water areas because wave- and current-induced turbulence tends to keep organic matter suspended in the water column longer than in deeper-water regions; hence more decomposition occurs in the water column and less organic matter is available to benthic organisms. Another possibility is that the majority of organic matter settling to deeper waters is consumed by filter-feeding benthos on hard-bottom areas, which comprise a large percentage of the Massachusetts Bay bottom (Knebel 1993). The organic material that eventually gets deposited into depositional areas may be relatively low quantitatively and extensively degraded (Garber 1984).

The release of nutrients from sediments is often a major source of nutrients fueling primary production in the overlying water column in shallow coastal systems. This was not the case in our study, however (Fig. 7). The estimated phytoplankton $\mathrm{N}$ and $\mathrm{P}$ requirement, calculated from the Redfield ratio and published rates of primary production, is 14.8 and $0.9 \mathrm{mmol} \mathrm{m}^{-2} \mathrm{~d}^{-1}$, respectively. The average $\mathrm{N}$ and $\mathrm{P}$ release during 1993 to 1994 at mid- and deep-water sites (MB01, 02, 03, vs 05) was 1.3 and $0.5 \mathrm{mmol} \mathrm{N} \mathrm{m} \mathrm{m}^{-2} \mathrm{~d}^{-1}$ (mid vs deep) and 111 to $100 \mu \mathrm{mol} \mathrm{P} \mathrm{m}^{-2} \mathrm{~d}^{-1}$ (mid vs deep), respectively. Thus benthic remineralization in mid-depth and deep waters, respectively, supplies sufficient nutrients to fuel only 3 to $8 \%$ of the $\mathrm{N}$ and 11 to $15 \%$ of the $\mathrm{P}$ requirements of phytoplankton. This is a relatively small amount, especially for the deep-water site. Further, the timing of $\mathrm{N}$ and $\mathrm{P}$ release from the benthos is not synchronized with phytoplankton requirements. Primary production is generally highest in spring and late summer, times when benthic remineralization is relatively low or exchange with surface waters is restricted due to strong density gradients. These estimates of the potential importance of benthic-derived nutrients may be inflated, because less than $30 \%$ of the bottom sediments on this continental shelf system are fine-grained depositional sediments (Knebel 1993). Whereas remineralization may be higher where filter-feeding benthos dominates, it may be less in sandy areas (see Hartwig 1976, Fisher et al. 1982).

Silica is one of the nutrients potentially limiting production of siliceous diatoms (Conley \& Malone 1992).
The depletion of $\mathrm{Si}$ following the spring bloom is thought to be one of the factors promoting a shift in species composition from diatoms to non-siliceous flagellates (Smayda 1989). Blooms of novel and toxic dinoflagellates, such as Alexandrium tamarense Lebour, have become a major environmental concern in the last few decades in coastal waters of the southwestern Gulf of Maine (Franks \& Anderson 1992). Regenerative Si fluxes from the benthos may be important in controlling the relative success of novel and toxic algae by enhancing diatom productivity. The benthos is a particularly important site of Si regeneration, because unlike $\mathrm{N}$ and $\mathrm{P}$, relatively little $\mathrm{Si}$ is regenerated in the water column prior to settling (Conley et al. 1993). The Si requirements of diatoms vary widely, but are generally in 1:1 ratio with inorganic $N$ (Brzezinski 1985). The average annual Si flux was $5.4 \mathrm{mmol} \mathrm{Si} \mathrm{m} \mathrm{m}^{-2}$ for Stns MB01, 02, 03, and 05. These regenerative fluxes are of such magnitude that diatoms could comprise up to about $37 \%$ of total phytoplankton production were rates in depositional areas to be extended to the entire region. Thus sediments are a major source of Si nutrition of phytoplankton in this continental shelf system.

In eutrophic coastal systems that experience substantial $\mathrm{N}$ loading from human activities on land, denitrification can be an important mechanism that retards eutrophication (Seitzinger 1988). In Boston Harbor, denitrification annually removes the equivalent of 8 to $15 \%$ of the total $\mathrm{N}$ load (Giblin et al. 1997, Nowicki et al. 1997). In fall 2000, the Massachusetts Water Resources Authority began diverting all sewage from the present outfall in Boston Harbor directly into bottom waters of Massachusetts Bay near Sites MB01, 02, and 03. The $\mathrm{N}$ load has been esti-

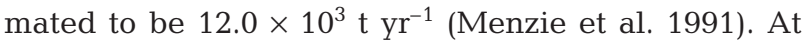
an average denitrification rate of $1.9 \mathrm{mmol} \mathrm{N} \mathrm{m}^{-2} \mathrm{~d}^{-1}$, denitrification in a $10 \times 10 \mathrm{~km}$ zone around the outfall could remove on the order of $10 \%$ of the load, similar to the amount currently being removed through denitrification in the harbor.

Acknowledgements. We extend our gratitude to numerous people who made this research possible, with respect to logistics and field and laboratory work. Funding was provided by the Massachusetts Water Resources Authority and Woods Hole Oceanographic Institution Sea Grant project \#NA46 RG04700. Boat captains Dave Olmstead and Chip Ryther got us to our sites safely. George Hampson and Hovey Clifford gave us on-site refresher courses in box core operations. Gary Banta and Dave Giehtbrock assisted in the field and laboritory and provided intellectual inspiration. Finally, Dan Conley helped with silicate analyses and interpretation. More detailed descriptions of methods and data summaries submitted by the authors to the Massachusetts Water Resources Authority can be found at the MWRA web page (e.g. for 1999 see: www.mwra.state.ma.us/harbor/enquad/pdf/1999-08.pdf). 


\section{LITERATURE CITED}

Aller R, Yingst J (1985) Effects of the marine deposit-feeders Heteromastus filiformis, Macoma balthica and Tellina texana on averaged sedimentary solute transport, reaction rates and microbial distributions. J Mar Res 43:615-645

Alpkem (1986a) Nitrate and nitrite in water and seawater. RFA Method Number A303-S171. Alpkem Corporation, Clackamas, OR

Alpkem (1986b) Silicates. RFA Method Number A303-S220. Alpkem Corporation, Clackamas, OR

Armstrong F (1951) The determination of silicate in seawater. J Mar Biol Assoc UK 30:1149-1160

Balzer W (1984) Organic matter degradation and biogenic element cycling in a nearshore sediment (Kiel Bight). Limnol Oceanogr 29:1231-1246

Bender ML, Jahnke R, Weiss R, Martin W, Heggie D, Orchardo J, Sowers T (1989) Organic carbon oxidation and benthic nitrogen and silica dynamics in San Clemente Basin, a continental borderland site. Geochim Cosmochim Acta 53:685-697

Berner RA (1980) Early diagenesis: a theoretical approach. Princeton University Press, Princeton, NJ

Billen G (1978) A budget of nitrogen cycling in North Sea sediments off the Belgian coast. Estuar Coast Mar Sci 7: $127-146$

Bishop JKB (1989) Regional extremes in particulate matter composition and flux. In: Berger W, Smetacek V, Wefer G (eds) Productivity of the ocean: present and past. John Wiley \& Sons, New York, p 117-137

Bohn HL (1971) Redox potentials. Soil Sci 112:39-45

Bothner M, Parmenter C, Brown A, Signell R (1990) Studies of circulation and pollutant transport in Massachusetts coastal waters. Rep US Geol Surv Open-File Rep 90-328

Boynton WR, Kemp W (2000) Influence of river flow and nutrient loads on selected ecosystem processes: a synthesis of Chesapeake Bay data. In: Hobbie J (ed) Estuarine science: a synthetic approach to research and practice. Island Press, Washington, DC, p 269-298

Boynton WR, Kemp W, Osbourne C (1980) Nutrient fluxes across the sediment-water interface in the turbid zone of a coastal plain estuary. In: Kennedy V (ed) Estuarine perspectives. John Wiley \& Sons, New York, p 93-109

Brzezinski M (1985) The Si:C:N ratio of marine diatoms: interspecific variability and the effect of some environmental variables. J Phycol 21:347-357

Butman B, Bothner M, Hathaway J, Knebel H, Manheim F, Signell R (1992) Contaminant transport and accumulation in Massachusetts Bay and Boston Harbor: a summary of U.S. Geological Survey studies. Rep US Geol Surv OpenFile Report 92-202

Cavari B, Phelps G (1977) Denitrification in Lake Kinneret in the presence of oxygen. Freshw Biol 7:385-391

Chatarpaul L, Robinson J, Kaushik N (1980) Effects of tubificid worms on denitrification and nitrification in stream sediment. Can J Fish Aquat Sci 37:656-663

Cline J (1969) Spectrophotometric determination of hydrogen sulfide in natural waters. Limnol Oceanogr 14:454-458

Codispoti LA (1989) Phosphorus vs nitrogen limitation of new and export production. In: Berger WH, Smetacek V, Wefer G (eds) Productivity of the ocean: present and past. John Wiley \& Sons, New York, p 377-394

Conley DJ, Malone T (1992) Annual cycle of dissolved silicate in Chesapeake Bay: implications for the production and fate of phytoplankton biomass. Mar Ecol Prog Ser 81: 121-128

Conley DJ, Schelske C, Stoermer E (1993) Modification of the biogeochemical cycle of silica with eutrophication. Mar Ecol Prog Ser 101:179-192

Devol AH, Christensen JP (1993) Benthic fluxes and nitrogen cycling in sediments of the continental margin of the eastern North Pacific. J Mar Res 51:345-372

Dollar S, Smith S, Vink S, Obresbski S, Hollibaugh J (1991) Annual cycle of benthic nutrient fluxes in Tomales Bay, California, and contribution of the benthos to total ecosystem metabolism. Mar Ecol Prog Ser 79:115-125

Dornblaser M, Tucker J, Banta G, Foreman K, O'Brien M, Giblin A (1989) Obtaining undisturbed sediment cores for biogeochemical studies. In: Lang M, Jaap W (eds) Proceedings of the 9th Annual Scientific Diving Symposium, American Academy of Underwater Sciences, Costa Mesa, CA, p 97-104

Edmond J (1970) High precision determination of titration alkalinity and total carbon dioxide content of seawater by potentiometric titration. Deep-Sea Res 17:737-750

Fisher T, Carlson P, Barber R (1982) Sediment nutrition regeneration in three North Carolina estuaries. Estuar Coast Shelf Sci 14:101-116

Franks P, Anderson D (1992) Alongshore transport of a toxic phytoplankton bloom in a buoyancy current: Alexandrium tamarense in the Gulf of Maine. Mar Biol 112:153-164

Garber J (1984) Laboratory study of nitrogen and phosphorus remineralization during the decomposition of coastal plankton and seston. Estuar Coast Shelf Sci 18:685-702

Giblin A, Hopkinson C, Tucker J (1997) Benthic metabolism and nutrient cycling in Boston Harbor, Massachusetts. Estuaries 20:346-364

Grundmanis V, Murray J (1977) Nitrification and denitrification in marine sediments from Puget Sound. Limnol Oceanogr 22:804-813

Hartwig EO (1976) Nutrient cycling between the water column and a marine sediment. I. Organic carbon. Mar Biol 34:285-295

Henriksen K, Hansen J, Blackburn T (1980) The influence of benthic infauna on exchange rates of inorganic nitrogen between sediment and water. Ophelia (Suppl) 1:249-256

Hopkinson CS (1985) Shallow-water benthic and pelagic metabolism: evidence of heterotrophy in the nearshore Georgia Bight. Mar Biol 87:19-32

Hopkinson CS (1987) Nutrient regeneration in shallow-water sediments of the estuarine plume region of the nearshore Georgia Bight, USA. Mar Biol 94:127-142

Hopkinson CS, Giblin AE, Tucker J, Garritt H (1999) Benthic metabolism and nutrient cycling along an estuarine salinity gradient. Estuaries 22:825-843

Jenkins M, Kemp WM (1984) The coupling of nitrification and denitrification in two estuarine sediments. Limnol Oceanogr 29:609-619

Joye SB, Hollibaugh JT (1995) Influence of sulfide inhibition of nitrification on nitrogen regeneration in sediments. Science 270:623-625

Kelly JR (1991) Nutrients and Massachusetts Bay: a synthesis of eutrophication issues. MWRA Environmental Quality Department Tech Rep Ser No. 91-10. Massachusetts Water Resources Authority, Boston, MA

Kelly JR, Doering P (1997) Monitoring and modeling primary production in coastal waters: studies in Massachusetts Bay 1992-1994. Mar Ecol Prog Ser 148:155-168

Kelly JR, Albro C, Geyer W (1995) High-resolution studies of water quality in Boston Harbor and Massachusetts Bay during 1994. MWRA Environmental Quality Department Tech Rep Ser No. 95-22. Massachusetts Water Resources Authority, Boston, MA

Kelly JR, Nowicki BL (1992) Direct measurements of denitrifi- 
cation in Boston Harbor and Massachusetts Bay sediments. Massachusetts Water Resources Authority, Boston, MA (Internal report)

Kemp WM, Boynton W (1984) Spatial and temporal coupling of nutrient inputs to estuarine primary production: the role of particulate transport and decomposition. Bull Mar Sci 35(3):522-535

Klump V, Martens C (1981) Biogeochemical cycling in an organic rich coastal marine basin. II. Nutrient sedimentwater exchange processes. Geochim Cosmochim Acta 45: 101-121

Knebel HJ (1993) Sedimentary environments within a glaciated estuarine-inner shelf system: Boston Harbor and Massachusetts Bay. Mar Geol 110:7-30

Li YH, Gregory S (1974) Diffusion of ions in seawater and in deep-sea sediments. Geochim Cosmochim Acta 38:703-714

Marinelli R, Jahnke R, Craven D, Nelson J, Eckman J (1998) Sediment nutrient dynamics on the South Atlantic Bight continental shelf. Limnol Oceanogr 43:1305-1320

Marquardt D (1963) An algorithm for least-squares estimation of nonlinear parameters. SIAM (Soc Ind Appl Math) SIMS (Siam Inst Math Soc) Conf Ser 11:431-441

Martin JH, Knauer G, Karl D, Broenlow W (1987) VERTEX: carbon cycling in the northeast Pacific. Deep-Sea Res 34: 267-286

Martin WR, Banta GT (1992) The measurement of sediment irrigation rates: a comparison of the $\mathrm{Br}$ - tracer and 222Rn/ 226Ra disequilibrium techniques. J Mar Res 50:125-154

McNichol AP, Lee C, Druffel E (1988) Carbon cycling in coastal sediments. 1. A quantitative estimate of the remineralization of organic carbon in the sediments from Buzzards Bay, MA. Geochim Cosmochim Acta 52:1531-1543

Menzie C, Cura J, Freshman J, Potocki B (1991) Boston Harbor: estimates of loadings. MWRA Environmental Quality Department Tech Rep Ser No. 91-4. Massachusetts Water Resources Authority, Boston, MA

Murphy J, Riley G (1962) A modified single solution method for the determination of phosphate in natural waters. Anal Chim Acta 27:31-36

Nixon SW (1981) Remineralization and nutrient cycling in coastal marine systems. In: Neilson B, Cronin L (eds) Estuaries and nutrients. Humana Press, Clifton, NJ, p 111-138

Nowicki BL, Kelly J, Requintina E, van Keuren D (1997) Nitrogen losses through sediment denitrification in Boston Harbor and Massachusetts Bay. Estuaries 20:626-639

Parsons TR, Takahashi M, Hargrave B (1984) Biological oceanographic processes. Pergamon Press, New York

Patrick WH, Khalid RA (1974) Phosphate release and sorption by soils and sediments: effect of aerobic and anaerobic conditions. Science 186:53-55

Editorial responsibility: Kenneth Tenore (Contributing Editor), Solomons, Maryland, USA
Price N, Harrison PJ (1987) Comparison of methods for the analysis of dissolved urea in seawater. Mar Biol 94: 307-317

Redfield AC (1958) The biological control of chemical factors in the environment. Am Sci 46:205-221

Rowe GT, Clifford C, Smith K (1975) Benthic nutrient regeneration and its coupling to primary productivity in coastal waters. Nature 255:215-217

Rowe GT, Clifford C, Smith K (1977) Nutrient regeneration in sediments off Cap Blanc, Spanish Sahara. Deep-Sea Res 24:57-63

Rowe GT, Theroux R, Phoel W, Quinby H, Wilke R, Koschoreck D, Whitledge T, Falkowski P, Fray C (1988) Benthic carbon budgets for the continental shelf south of New England. Contin Shelf Res 8:511-528

Ryther JH, Dunstan WH (1971) Nitrogen, phosphorus and eutrophication in the coastal marine environment. Science 171:1008-1013

Seitzinger S (1988) Denitrification in freshwater and coastal marine ecosystems: ecological and geochemical significance. Limnol Oceanogr 33:702-724

Seitzinger S, Giblin A (1996) Estimating denitrification in North Atlantic continental shelf sediments. Biogeochemistry 35:235-260

Slater J, Capone D (1987) Denitrification in aquifer soils and nearshore marine sediments influenced by groundwater nitrate. Appl Environ Microbiol 53:1292-1297

Smayda TJ (1989) Primary production and the global epidemic of phytoplankton blooms in the sea: a linkage? In: Cosper E, Bricelj V, Carpenter E (eds) Coastal and estuarine studies. Vol 35. Novel phytoplankton blooms. Springer-Verlag, New York, p 449-483

Smith KL, White G, Laver M, Haugsness J (1978) Nutrient exchange and oxygen consumption by deep-sea benthic communities: preliminary in situ measurements. Limnol Oceanogr 23:997-1005

Smith SV, Hollibaugh JT (1993) Coastal metabolism and the oceanic organic C balance. Rev Geophys 31:75-89

Solórzano L (1969) Determination of ammonia in natural waters by the phenolhypochlorite method. Limnol Oceanogr 14:709-801

Sørensen J (1978) Denitrification rates in a marine sediment as measured by the acetylene inhibition technique. Appl Environ Microbiol 36:139-143

Strickland JDH, Parsons TR (1972) A practical handbook of seawater analysis, 2nd edn. Bull Fish Res Board Can 167:310

Tsunogai S, Nishimura N, Nakaya S (1968) Complexometric titration of calcium in the presence of larger amounts of magnesium. Talanta 15:385-390

Submitted: April 24, 2000; Accepted: January 29, 2001

Proofs received from author(s): November 26, 2001 